\title{
PLURIOFENSIVIDAD DE LOS DELITOS DE CORRUPCIÓN EN LAS TRANSACCIONES COMERCIALES INTERNACIONALES: CORRUPCIÓN Y COHECHO
}

\author{
Ana Parés López de Lemos \\ Doctora en Derecho \\ Profesora en la UNIR y Abogada en ECIJA \\ apares@ecija.com
}

\begin{abstract}
RESUMEN
Las transacciones comerciales internacionales conforman el vasto ámbito donde se inserta la corrupción dentro del contexto de la cultura social, económica y política, y su crecimiento. En coherencia con la asunción de los compromisos internacionales suscritos por España a través de las ratificaciones de convenios internacionales, se introdujo este injusto en el Código Penal español y se reformó en varias ocasiones, marcando un bito la última reforma legislativa de 2015. La lesión al bien juridico protegido de este tipo de cohechos transnacionales es de carácter pluriofensivo. España muestra un cierto grado de madurez en la lucha contra este tipo de corrupción semipública internacional, aunque en la persecución de tales delitos todavia se hace preciso desarrollar mejoras técnicas y multidisciplinares.
\end{abstract}

Palabras clave: Derecho penal, corrupción, cohecho, soborno, comercio internacional, globalización.

\section{ABSTRACT}

International business transactions make a vast field where to put corruption within the context of social, economic and political culture and where to put its development. This wrongful case was introduced in Spanish Penal Code within the logical assumption of international compromises subscribed by Spain through the approval of International Conventions. It was modified later on and the latest legal reform of 2015 reached a milestone: injuries on the legal good protected of such type of multi offensive transactional briberies. Spain proves to have a certain degree of maturity against such type of international semi-public corruption, although the prosecution of such crimes still needs improvement both technically and multidisciplinary speaking.

Keywords: Penal Law, corruption, bribery, international law, globalization.

\section{ZUSSAMENFASSUNG}

Der internationale Geschäftsverkebr stellt das breite Umfeld dar, in dem Korruption in den Kontext der sozialen, wirtschaftlichen und politischen Kultur eindringt und 
wächst. Im Einklang mit der Übernabme der internationalen Verpflichtungen, die von Spanien ratifiziert wurden, gelangte dieser ungerechte Tatbestand in das Spanische Strafgesetzbuch und wurde mebrfach reformiert, wobei die letzte Strafreform von 2015 einen Meilenstein darstellt: Die Verletzung des geschützten Rechtsguts durch diese Art von transnationalen Bestechungen in Form einer Tatmehrbeit. Spanien zeigt eine gewisse Reife im Kampf gegen diese Art von halböffentlicher internationaler Korruption, obwobl es bei der Strafverfolgung dieser Straftaten weiterbin notwendig ist, technische und disziplinübergreifende Verbesserungen vorzunehmen.

Schlüsselwörter: Strafrecht, Korruption, Bestechung, Schmiergeld, internationaler Handel, Globalisierung.

SUMARIO: I. INTRODUCCIÓN.-II. CONTEXTUALIZACIÓN DE LA CORRUPCIÓN.-1. Breve referencia metapenal de la corrupción en un marco jurídico global.-2. Aproximación a la figura delictiva de soborno y su regulación a partir de la codificación.-III. COMPROMISOS INTERNACIONALES Y NACIONALES PARA COMBATIR EL COHECHO TRANSNACIONAL.-1. Iniciativas normativas internacionales.-2. Iniciativas normativas en la Unión Europea.-3. Ratificación de España de los documentos internacionales y evaluación de su trasposición en la lucha contra la corrupción de los delitos de corrupción en las transacciones comerciales internacionales.-IV. EL COHECHO PLURIOFENSIVO DE LOS DELITOS DEL ART. 286 TER DEL CÓDIGO PENAL.-1. Lesión de intereses colectivos en la corrupción.-2. Intereses jurídicos que componen el bien jurídico protegido de los delitos del art. 286 ter--A. Similitudes con el bien jurídico protegido en la corrupción entre particulares.-B. Paralelismo con el bien jurídico protegido en el delito de cohecho.-C. Concreción del bien jurídico protegido en los delitos de corrupción en las transacciones comerciales internacionales.-V. CONCLUSIONES.-VI. BIBLIOGRAFÍA.

\section{INTRODUCCIÓN}

En un contexto socioeconómico de armonización legislativa —entendida como un proceso impulsado por el legislador para lograr la unificación de sistemas jurídicos - se inscribe la realidad político-económica europea y española, donde las transacciones comerciales internacionales y las defraudaciones (y, en especial, la corrupción) han sido una tradición de interés exclusivo del Derecho interno, al igual que su punibilidad y tipicidad. Ahora, sin embargo, ante la globalización de las relaciones comerciales, resulta de mayor facilidad su comisión por haberse implantado el elemento transnacional de forma expansiva y, por ende, la corrupción con agentes públicos extranjeros, y ello ataca el correcto funcionamiento del tráfico económico internacional. La corrupción viene siendo un fenómeno histórico, social y político que hoy afecta tanto al sector público como al privado. 
Surge la preocupación a nivel internacional, y, en consecuencia, también a nivel nacional, por combatir y erradicar las conductas delictivas de la corrupción, que van evolucionando más rápido que la propia previsión legislativa de su castigo y represión. Aquí se aborda la corrupción que se erige desde la vertiente pública mediante la intervención de un funcionario público, para atacar el sector privado en el plano supranacional. El riesgo de una comisión generalizada reside en que, debido a su reiteración y su desarrollo dentro de la opacidad entre los huecos de lo público y lo privado en el ámbito internacional, corre el peligro de convertirse en sistémica ${ }^{1}$, lo cual dificulta enormemente su lucha y erradicación. La criminalidad organizada, o más bien la criminalidad de empresa ${ }^{2}$, es aquella que, con tintes políticos, actúa en el plano transnacional entre dichos sectores, el público y el privado. Las dificultades para su persecución han de buscarse en la relevancia social que adquieren los hechos delictivos, en el estatus socioeconómico de los sujetos, así como en los concursos de delitos que oscurecen su detección y facilitan su impunidad.

El soborno de funcionarios públicos de otros Estados en el transcurso de operaciones comerciales internacionales es un hecho habitual en el seno de grandes empresas multinacionales, si bien sólo los casos de mayor alcance adquieren repercusión mediática.

Hoy día, con base en el carácter transfronterizo de las operaciones, la corrupción representa un asunto económico con incidencia en la competitividad dentro de la economía global y en la eficacia de los proyectos de inversión y de desarrollo en todo el mundo ${ }^{3}$. Los delitos de corrupción en las transacciones comerciales internacionales producen un impacto negativo en los sistemas democráticos, en las economías de mercado del mundo occidental y, en especial, en España. Las consecuencias generales de la corrupción trascienden el ámbito internacional y repercuten, a su vez, sobre los ámbitos nacional y local.

${ }^{1}$ M. A. Iglesias Río y T. Medina Arnáiz, «Herramientas preventivas en la lucha contra la corrupción en el ámbito de Unión Europea» en AAVV, Anuario de Derecho Constitucional Latinoamericano, t. II, Montevideo, Konrad Adenauer Stiftung, 2004, p. 906.

2 Denominada también criminalidad empresarial por la Fiscalía General del Estado, Circular 1/2016 sobre la responsabilidad penal de las personas jurídicas conforme a la reforma del Código Penal efectuada por Ley Orgánica 1/2015, disponible en bttps://www.fiscal.es/fiscal/PA _WebApp_SGNTJ_NFIS/descarga/CIRCULAR\%201-2016\%20-\%20PERSONAS\%20JUR\%C 3\%8DDICAS.pdf? idFile $=$ cc42d8fd-09e1-4f5b-b38a-447f4f63a041.

3 S. Rose Ackermann, Corruption: A Study in Political Economy, New York, Academic Press University of Yale, 1978, pp. 25-59. 
Los instrumentos internacionales en la lucha contra la corrupción no han logrado todavía instaurar una verdadera cultura contra la misma. Se hace necesaria la implicación de los gobiernos, los funcionarios, las empresas y la sociedad civil, que continúa siendo insuficiente ${ }^{4}$.

La enormemente variada y dispersa casuística de las conductas corruptas y la insuficiente tipificación penal y procesal reflejan el grave problema económico, social, político y moral, especialmente en muchos países emergentes, afectando de forma singular a las empresas a través de sobornos en las transacciones internacionales, tanto comerciales como financieras o tecnológicas. La ilicitud de esas transacciones, provenientes de un soborno, constituyen conductas fraudulentas que corrompen los principios de la seguridad jurídica nacional y supranacional, con objeto de conseguir fines particulares contrarios al bien común y a la seguridad colectiva.

$\mathrm{El}$ incremento de los delitos de corrupción internacional se debe, entre otras razones, a una degenerativa privatización de muchos servicios públicos, lo cual ha generado falta de claridad en la delimitación de la función pública y la función privada. Asimismo, hay que incidir en el aumento global de las transacciones comerciales internacionales en el campo financiero, muchas de ellas fraudulentas. Habitualmente, la corrupción dentro del sector privado en sus relaciones con el sector público se lleva a cabo a través del soborno y las operaciones comerciales internacionales, que constituyen un convenio, es decir, un acuerdo de voluntades entre dos agentes distintos, quienes, en ocasiones, pueden transigir en sus posturas y criterios para lograr de esta forma bien un fin común, bien una contraprestación en el ámbito comercial o supranacional. A través de la voluntad política de los distintos líderes, España se ha esforzado en aprovechar la capacidad institucional para poner en práctica las medidas recomendadas por los organismos internacionales y por la Unión Europea con objeto de lograr una transparencia pública y un compromiso responsable con la sociedad. En consonancia con lo anterior, sorprende en extremo que no existan apenas casos de condena en España por el delito de corrupción en las transacciones comerciales internacionales, y que el informe del grupo de trabajo de la Organización para la Cooperación del Desarrollo Econó-

${ }^{4}$ En este sentido caben destacar las conclusiones publicadas por la Organización para la Cooperación y el Desarrollo Económico, donde se pone de manifiesto que veinte de los treinta y cuatro países evaluados, ratificadores de la Convención contra el Soborno Transnacional del año 1997, no ban implantado correctamente dicha Convención ni están manteniendo sus compromisos anticorrupción (disponible en http://www.oecd.org/daf/anti-bribery/ AntiBriberyAnnRep2012.pdf). 
mico ${ }^{5}$ para España ponga de relieve multitud de vacíos legislativos en la regulación de la materia y del injusto, los cuales no han sido paliados en su totalidad a través de la nueva introducción y cambio de ubicación sistemática del delito de corrupción en las transacciones comerciales internacionales tras la última reforma legislativa del Código Penal $(\mathrm{CP})^{6}$.

Los delitos de corrupción en las transacciones comerciales internacionales como tipología de conductas corruptas constituyen un delito en evolución hacia otras formas de comisión cada vez más intrincadas. El soborno es un fenómeno ampliamente difundido en las transacciones comerciales internacionales, incluidos el comercio y la inversión, si bien el eje fundamental o nexo de unión lo constituye la presencia de un servidor público. He ahí la gravedad de las consecuencias: el surgimiento de serias complicaciones de carácter ético y político, y la destrucción del buen gobierno y el desarrollo económico, amén de la distorsión de las condiciones competitivas internacionales. La corrupción con agentes públicos extranjeros es una realidad que se nutre de las lagunas legislativas para lograr la impunidad en España respecto a los requisitos para su persecución, a los problemas de autoría y participación que existen en las empresas multinacionales, y a la utilización de terceros intermediarios, dado que además no existe en España la tipificación de la corrupción pasiva de tales conductas.

\section{CONTEXTUALIZACIÓN DE LA CORRUPCIÓN}

\section{Breve referencia metapenal de la corrupción en un marco jurídico global}

La corrupción se identifica con la utilización de una autoridad establecida para el bien de una comunidad determinada en beneficio indebido de quien ejerce esa autoridad. Etimológicamente, la palabra corrupción procede del latín «corruptus», que significaba descomposición, desintegración. En la actualidad es definida por la Academia de la Lengua Española como

${ }^{5}$ Informes sobre la implementación en España del Acuerdo de la Organización para la Cooperación del Desarrollo Económico para luchar contra la corrupción de agentes públicos extranjeros de 1997, en diciembre de 2012 (disponible en bttp://www.oecd.org/daf/anti -bribery/Spainphase3reportEN.pdf), en diciembre de 2014 (disponible en bttp://www.oecd.org/ corruption/oecd-foreign-bribery-report-9789264226616-en.htm) y en marzo de 2015 (disponible en bttp://www.oecd.org/daf/anti-bribery/Spain-Phase-3-Written-Follow-Up-Report-EN.pdf).

${ }^{6}$ LO 1/2015 por la que se modifica la LO 10/1995, de 23 de noviembre, del Código Penal (BOE, núm. 77, de 31 de marzo de 2015). 
«acción y efecto de corromper», lo que a su vez se define como «alterar y trastocar la forma de alguna cosa»; en su caso, también como «echar a perder, depravar, dañar, pudrir»o «sobornar a alguien con dádivas o de otra manera» ${ }^{7}$, e incluso como «pervertir o seducir a una persona»; asimismo, «práctica consistente en la utilización de las funciones y medios de aquellas en provecho, económico o de otra índole, de sus gestores» ${ }^{8}$. No se puede determinar con exactitud cuándo comenzó la corrupción y el soborno a funcionarios públicos, pero existen testimonios de tal práctica a lo largo de la historia y en todas las culturas.

La corrupción está vinculada al sistema normativo concreto en el que se inserta y desarrolla. La corrupción es eminentemente política y se asienta sobre un agente público con autoridad, sin perjuicio de la antigua concepción de Maquiavelo, con base en la cual los deseos humanos son insaciables, pues la naturaleza humana desea y quiere todo, surgiendo de ello una eterna insatisfacción ${ }^{9}$. En este sentido, todo agente sujeto a obligaciones es susceptible de corromperse y todo sistema normativo es potencialmente corrupto. Pero dejando al margen consideraciones tan radicales y subjetivas, resulta un hecho indiscutible que la corrupción socioeconómica ha continuado incrustada en todas las épocas de nuestra historia.

En los tiempos actuales, un hito histórico merecedor de atención fue el creciente interés de la comunidad internacional por combatir la corrupción a partir de la necesidad de un replanteamiento general de la estructuración y competencias de los organismos internacionales de ayuda y de crédito. Sin embargo, la influencia de la corrupción generalizada y de la delincuencia organizada en muchos países supuso un problema añadido difícil de ignorar y aún más difícil de encarar, porque, en definitiva, al tratarse la corrupción de un asunto económico se ve afectada la competitividad de la economía global y la realización eficaz de los proyectos de inversión y de desarrollo en el mundo entero ${ }^{10}$.

En sentido amplio, la corrupción ${ }^{11}$ siempre ha representado la degeneración de los principios por los que se rige una sociedad, así como el abuso de funciones y los recursos públicos para el beneficio privado, en su caso,

7 Real Academia Española, Diccionario de la Lengua Española, 22. ${ }^{a}$ ed., Madrid, Espasa, 2001, pp. 393-394, 451 y 1409.

8 Voz «corrupción», en www.lema.rae.es/drae/?val=CORRUPCION.

9 N. Maquiavelo y A. Aracón Martínez, Discursos sobre la primera década de Tito Livio, Madrid, Alianza Editorial, 1987, pp. 6-9.

${ }_{10}$ S. Rose Ackermann, Corruption..., op. cit..., pp. 17-81.

${ }^{11} \mathrm{Voz}$ «corrupción», en Diccionario de la Lengua..., op. cit. 
como una forma social de intercambio secreto por el cual los que detentan el poder político y administrativo obtienen un beneficio, de un tipo o de otro, del poder o de la influencia que ejercen en virtud de su posición o función. La corrupción por naturaleza no constituye un concepto jurídico. Ha sido la doctrina y el propio ordenamiento jurídico los que han ido atribuyendo un significado normativo al término corrupción, aunque ello en función del contexto en el que se inserta. Puede afirmarse que en el plano jurídico la corrupción será lo que la normativa defina como tal en cada momento y en cada campo ${ }^{12}$. En el ámbito penal, la corrupción debe circunscribirse con atención al principio de intervención mínima del Derecho penal como límite coherente con la lógica del Estado contemporáneo, que busca el mayor bienestar con el menor coste social, de acuerdo con el actual postulado utilitarista ${ }^{13}$. Íntimamente ligado a este principio se sitúa el principio de exclusiva protección de bienes jurídicos, el cual sirve como límite al ius puniendi, debiendo el Derecho penal sancionar sólo la puesta en peligro y el ataque más grave a aquellos bienes jurídicos más relevantes ${ }^{14}$. El Tribunal Constitucional (TC) entiende que este principio deviene, además, un requisito indispensable para cualquier limitación de derechos constitucionales ${ }^{15}$. El objetivo se fundamenta en la selección de los objetos, medios e instrumentos para controlar la criminalidad, y por esa razón ha de ser siempre el Derecho penal la ultima ratio ${ }^{16}$, es decir, interceder en casos de estricta necesidad y defender así bienes jurídicos fundamentales de los ataques más graves de la corrupción, cuando no existan otras garantías de éxito de naturaleza no penal.

La corrupción penal puede entenderse como la utilización de una autoridad establecida para el bien de una comunidad determinada en beneficio indebido de quien ejerce esa autoridad y del particular que soborna. Se incumplen determinadas funciones sociales para obtener un beneficio para

12 E. Fabián CAPARRós, La corrupción de agente público extranjero e internacional, Valencia, Tirant lo Blanch, 2003, p. 22.

${ }_{13}$ S. Mir Puig, Derecho penal. Parte general, 9." ed., Barcelona, Reppertor, 2011, pp. 103 y 104.

14 T. Aguado Correa, El principio de proporcionalidad en Derecho penal, Madrid, Edersa, 1999, pp. 113-135.

${ }^{15}$ J. M. Zugaldía Espinar (dir.) y M. J. Moreno Torres Herrera (coord.), Lecciones de Derecho penal (parte general), 2. ${ }^{a}$ ed. adaptada a la reforma del Código Penal aprobada por las Leyes Orgánicas 1 y 2/2015, de 30 de marzo, Valencia, Tirant lo Blanch, 2015, pp. 50 y 51. En este sentido también la jurisprudencia se pronunció en las SSTC 111/1993, de 25 de marzo, y 55/1996, de 28 de marzo.

${ }^{16}$ J. M. Zugaldía Espinar (dir.) y M. J. Moreno Torres Herrera (coord.), Lecciones de Derecho penal..., op. cit., pp. 49-51. 
sí o para un tercero ${ }^{17}$. Esta concepción debe contemplarse con la afirmación de Kindhäuser relativa a la significación de la corrupción penal, para quien los elementos centrales que caracterizan la corrupción desde una perspectiva penal pueden resumirse en tres: en primer lugar, la corrupción supone una relación entre dos agentes que pactan un intercambio irregular de prestaciones entre el receptor de la ventaja y el otorgante de la misma (debe existir un pactum scaeleris que produzca recíprocas obligaciones y beneficios irregulares); en segundo lugar, debe concurrir una especial posición de garante de quien recibe la dádiva a fin de que transgreda los principios del sistema institucional o del mercado, y, en tercer lugar, debe existir una incompatibilidad de intereses entre la ventaja o dádiva obtenida y la especial posición en la que se encuentra el receptor.

La corrupción puede constituir una forma de agresión de diversos intereses penalmente protegidos y por ello no puede formularse un tipo penal general de corrupción. Lo determinante para la legitimidad del ius puniendi es la circunstancia de que el sujeto activo haya puesto en peligro o haya lesionado un bien jurídico protegido a través de la corrupción ${ }^{18}$. Desde un punto de vista criminológico se ha venido analizando la característica de los sujetos de alta reputación social, delincuencia de cuello blanco ${ }^{19}$, y el abuso de confianza institucionalizado con el fin de alterar las reglas de los sectores público y privado. Hoy día la política criminal más reciente también responsabiliza a las empresas en la lucha contra la corrupción ${ }^{20}$, ya que son potenciales sujetos activos de tales delitos.

${ }_{17}$ C. Nino, Un país al margen de la ley, 1. ${ }^{\text {a }}$ ed., Buenos Aires, Ariel, 2005, p. 109.

18 U. KINDHÄUSER, «Presupuestos de la corrupción punible en el Estado, la economía y la sociedad. Los delitos de corrupción en el Código Penal alemán», Política Criminal. Revista electrónica semestral de políticas públicas en materias penales, núm. 3 (2007), p. 6, disponible en bttp://www.politicacriminal.cl/n_03/a_1_3.pdf.

19 El término «delincuencia económica de cuello blanco» es la traducción literal del White-Collar Criminality utilizado por primera vez por E. H. SuTHERLAND en American Sociological Society en 1939 para definir a la persona de alto nivel socioeconómico que en el desarrollo de su actividad profesional viola la ley penal, citado por M. BAJO FERNÁNDEZ, «La delincuencia económica. Un enfoque criminológico y político criminal», en M. BARBERO Santos, Estudios penales. Libro homenaje al profesor Doctor D. José Antón Oneca, Salamanca, Universidad de Salamanca, 1982, p. 587. Sin embargo, el término delincuencia de cuello blanco ha quedado actualmente algo desfasado, pues en lo que concierne a los delitos de corrupción en las transacciones comerciales internacionales es la delincuencia empresarial la que deberá perseguirse. La delincuencia de empresa goza de cierta reputación social y económica, pero, a diferencia de la delincuencia organizada, parte de una estructura legal para acometer luego los ilícitos penales.

${ }^{20}$ L. Arroyo Zapatero y A. Nieto Martín, El Derecho penal económico en la era compliance, Valencia, Tirant lo Blanch, 2013, pp. 191-192. 
Este tipo de corrupción suele vincularse con el Derecho penal económico, el cual en sentido dogmático penal protege bienes supraindividuales, es decir, sociales o colectivos, o intereses de la comunidad ${ }^{21}$. Los delitos económicos trascienden en ocasiones el ámbito internacional, debido al carácter transnacional de los sujetos y a la transversalidad de las conductas ${ }^{22}$.

El fenómeno de la corrupción es el mal más común y relevante que sufren tanto los sistemas democráticos como aquellos otros sistemas políticos menos democráticos o en decadencia que abogan por la corrupción para su mantenimiento y prospección ilegítima. Los problemas crecientes del sector público, desde el punto de vista de la economía de mercado, se constriñen a los fallos de gobierno, lo que a su vez cuestiona la capacidad de producción y planificación del Estado. Si bien existen algunos economistas que ponen en duda determinadas teorías con objeto de corregir los fallos del mercado, son prácticamente unánimes las opiniones que defienden la necesidad de la regulación y transparencia para paliar y prevenir las consecuencias de la corrupción ${ }^{23}$. Existe el riesgo de que la injerencia en la regulación del mercado y la competencia suponga una distorsión a favor del sector privado a expensas de los usuarios o de la sociedad. La regulación debe equiparar de forma proporcionada los intereses del sector privado, los intereses y derechos de los ciudadanos y de la sociedad, garantizando así una prestación eficaz y efectiva de los servicios, así como una oferta real y equitativa de los productos del mercado. Según todos los analistas, un mecanismo eficaz contra la corrupción es la competencia real, económica y política, porque de esta manera se introduce la transparencia ${ }^{24}$. Las políticas que buscan incentivar mercados competitivos pueden controlar la corrupción a través de una regulación normativa y la utilización de unos recursos adecuados y suficientes ${ }^{25}$.

${ }^{21}$ K. Tiedemann, Manual de Derecho penal económico. Parte general y especial, Valencia, Tirant lo Blanch, 2010, pp. 57 y 58

${ }^{22}$ El Derecho penal económico parte de aspectos supraindividuales de planificación económica y social de una forma parecida a lo que ocurre en el Derecho económico. Estos tipos de delitos constituyen la forma de reacción adecuada del Derecho penal dentro del ámbito de los bienes jurídicos supraindividuales y colectivos. Vid. «Empfehlungen des XIII. Internationalen Strafrechtskongresses der AIDP» («Recomendaciones del XIII Congreso Internacional de Derecho penal de la AIDP»), ZStW, t. 97 (1985), pp. 731-738.

${ }^{23}$ K. Tiedemann, Manual de Derecho penal económico...., op. cit., pp. 245-263.

${ }^{24}$ M. Johnston, «Party System, Competition and Political Checks against Corruption», en A. J. Heidenheimer y M. Johnston (eds.), Political Corruption. Concepts E Contexts, 3. ' ed., New Brunswick, Transaction Publishers, 2002, pp. 777-794.

25 A. Ades y R. DI Tella, «Rents, Competition and Corruption», American Economic Review, vol. 89, núm. 4 (1999), pp. 982-993. 
En España, hasta la reciente reforma penal de 2010, las penas de corrupción de los funcionarios públicos eran mayores que las de los particulares, y el número de conductas sancionadas, tales como la corrupción, era mayor en el caso de funcionarios públicos ${ }^{26}$. La corrupción tiene un amplio espectro de consecuencias corrosivas para la sociedad ${ }^{27}$, afecta en mayor medida a los individuos sin recursos económicos, ya que desvía fondos destinados al desarrollo, y mina la capacidad de los gobiernos para ofrecer servicios básicos, intimidando así la inversión extranjera o ayudas internacionales o comunitarias. Sin embargo, la corrupción no se debe tratar desde una óptica moral, cuyos límites resultan culturalmente difusos. La corrupción existe y se tiene que abordar a partir de una perspectiva multidisciplinar: política, económica, social y legal. Se trata de un problema de gran trascendencia en el ámbito internacional y constituye una fuente de empobrecimiento en los países en vías de desarrollo. Ésa es la razón de que los países donantes de ayuda deban ejecutar programas sistematizados y evitar la corrupción endógena instalada en los gobiernos de dichos países, cuyo alcance resulta difícil de evaluar desde el exterior. Por ello, todo análisis que pueda realizarse sobre la corrupción siempre será de índole empírica y estará basado en los índices de percepción.

Ante la multiplicidad de conceptos que engloba el término de la corrupción, el legislador se encontró con un concepto jurídico vago que no ha sabido tampoco precisar con exactitud, y en relación con el Derecho penal, a pesar de la ayuda que la ciencia de la política criminal podría aportar, tampoco ha logrado delimitarlo. Es más, una posible definición penal ha de buscarse en el casuismo de las distintas conductas corruptas tipificadas.

También hay que apuntar que en años recientes se han podido comprobar las nefastas consecuencias que ha provocado la corrupción, gracias al mejor conocimiento de los procesos internos de dirección en las empresas, a la toma de conciencia de las oportunidades creadas en un mundo globalizado y a los costes derivados de las discriminaciones y las conductas injustas. A través de la divulgación de las conductas corruptas y los modernos medios de comunicación se ha alcanzado un mayor conocimiento y también una mayor preocupación sobre la extensión y profundidad del fenó-

${ }^{26}$ A. Nieto Martín, «La corrupción en el comercio internacional (o de cómo la americanización del Derecho penal puede tener de vez en cuando algún efecto positivo)», Revista Penal, núm. 12, (2003), pp. 47-53.

27 UNCAC, Prefacio, A. Kofi Annan (secretario general), Resolución 58/4 de la Asamblea General, de 31 de octubre de 2003, Nueva York, 2004, disponible en bttp://www. unodc.org/documents/treaties/UNCAC/Publications/Convention/04-56163_S.pdf. 
meno de la corrupción. Afecta a todas las economías, pero los perjuicios son soportados directamente por los particulares, las empresas y los países comprometidos. Así pues, resultan de suma importancia las iniciativas legislativas en la prevención y la erradicación de los comportamientos corruptos como medio para ganar en justicia, eficiencia, solidaridad, libertad y democracia.

Una de las causas de los intentos frustrados para reconducir la actuación y posicionamiento de las empresas multinacionales en el marco de la globalización se ha debido al vacío jurídico en el Derecho internacional, pues no existe una jurisdicción internacional con competencias para juzgar a las personas jurídicas privadas transnacionales. Tampoco existe organismo alguno en el que se inscriba una personalidad jurídica internacional, porque, además, los códigos de conducta dictaminados por la Organización de Cooperación al Desarrollo Económico (OCDE) son de adscripción y cumplimiento voluntarios ${ }^{28}$. La política liberalizadora propugnada por la Organización Mundial del Comercio (OMC) ha favorecido en gran medida a las empresas multinacionales para actuar exclusivamente en beneficio de sus intereses económicos partidistas. Tales conductas quebrantan el principio de igualdad, el correcto desenvolvimiento de un mercado económico real y el adecuado y diligente funcionamiento de las administraciones y organismos públicos de cuño internacional. Las Naciones Unidas (ONU) intentaron darle «un rostro humano» a los mercados globales mediante su programa Global Compact ${ }^{29}$; sin embargo, los intentos sucesivos por regular y humanizar la globalización en pro de los derechos básicos humanos y de los ciudadanos no tuvo apenas efecto en aquellos países cuya preocupación en la lucha contra la corrupción residía, principalmente, en evitar las pérdidas financieras que ésta provoca.

No hay que olvidar, una vez más, que la corrupción comprende un amplio espectro de consecuencias corrosivas para la sociedad: «Socava la democracia y el Estado de Derecho, da pie a violaciones de derechos humanos, distorsiona los mercados, menoscaba la calidad de vida y permite el florecimiento de la delincuencia organizada, el terrorismo y otras amenazas a la seguridad humana» ${ }^{30}$.

${ }^{28}$ Líneas directrices de la OCDE para empresas multinacionales, revisión 2011, disponible en bttp://www.oecd.org/daf/inv/mne/MNEguidelinesESPANOL.pdf.

${ }^{29}$ United Nations Global Compact (bttps://www.unglobalcompact.org/).

${ }^{30}$ UNCAC, Prefacio, Kofi A. Annan (secretario general), Resolución 58/4 de la Asamblea General, op. cit. 


\section{Aproximación a la figura delictiva «soborno» y su regulación a partir de la codificación}

Una concepción estricta de la corrupción conduce a lo que en Derecho español se denomina cohecho. Es creciente la tendencia criminológica a identificar la corrupción con cualquier irregularidad cometida en un contexto de toma de decisión a cambio de una ventaja indebida, toda vez que a través de un abuso de poder se llegue a una ganancia ilícita. Dicho beneficio indebido puede ser de carácter económico o significar una mejora del posicionamiento para el desarrollo de determinadas actividades, algo que se produce fundamentalmente en el marco de la Administración, pero que también puede aparecer en las relaciones económicas nacionales e internacionales ${ }^{31}$.

A lo largo de las épocas anteriores hasta la actual y en todos los periodos históricos citados, el soborno a grupos sociales dominantes se encontraba ampliamente extendido, pues constituía un acto habitual. El soborno no estaba permitido, pero se toleraba, y únicamente cuando el delito alcanzaba notoriedad o valor grave se redimía con el pago de una suma de dinero impuesta por la jerarquía: nobles, obispos o jueces, según la época. Esta situación se incardina en la evolución social e histórica del Derecho romano y alcanza la promulgación del Código Civil (CC) de $1889^{32}$.

El cohecho se definió como exacción ilícita en el siglo XIII, significando una transacción o arreglo de un asunto, mientras que cohechar, del latín confectare o acabar de negociar, consistía en corromper a un funcionario público ${ }^{33}$.

El soborno es una de las formas más antiguas y comunes de las prácticas fraudulentas en los negocios. El cohecho como tipo delictivo, por un lado, puede lesionar el correcto funcionamiento de la Administración Pública estatal o extranjera si se realiza a través de agentes públicos extranjeros y, por otro, también puede alterar el correcto funcionamiento del mercado económico internacional.

La corrupción, incidiendo de nuevo en el concepto básico, es tan antigua como la propia Administración Pública: la pretensión de obtener de

${ }^{31}$ J. L. DE LA Cuesta ARZAmendi, «Iniciativas internacionales contra la corrupción», Eguzkilore, núm. 17 (2003), p. 8.

32 C. SÁnchez Albornoz, España: un enigma histórico, vol. II, Argentina, Edhasa, 1991, pp. 293-354.

33 J. Corominas, Diccionario crítico etimológico castellano e hispánico, vol. I, A-C, Madrid, Gredos, 1954-1957, p. 785. 
ella algún tipo de trato favorable en contra de sus normales reglas de funcionamiento y las del tráfico económico. Desde que existen funcionarios que administran lo público, existen tanto personas particulares dispuestas a sobornarlos para poder beneficiarse con sus actuaciones como también funcionarios que vislumbran la posibilidad de sacar un mayor beneficio a su trabajo o a su posición preeminente, cobrando a los administrados por priorizar sus intereses en el sector público o privado y prevaliéndose de su condición para realizar dicha maniobra.

La primera regulación del cohecho se remonta al sistema jurídico romano-visigodo, que contemplaba la institución del «crimen repundae» en la «lex Julia repetundarum», la cual sancionaba con multa pecuniaria y destierro el acto de aceptar el soborno. Su regulación responde a la finalidad de combatir la corrupción en el ejercicio de las funciones públicas, concretamente respecto del magistrado u oficial; una corrupción que era imperante y frecuente en todas las épocas, pero en particular en las de inmoralidad generalizada en los puestos administrativos del Imperio Romano.

El cohecho se sancionaba en función del interés general, por cuanto que, constituyendo un enriquecimiento ilícito, se exigía al funcionario la devolución de lo obtenido en la venta de un acto de la Administración Pública ${ }^{34}$. La influencia romana en la regulación de nuestro Derecho castellano propició su desarrollo legislativo y conceptual, tanto en el sistema jurídico altomedieval como en el de la Recopilación, época en la que los textos vigentes (El Fuero Real, Las Partidas y el Ordenamiento de Alcalá) recogen la figura del cohecho como acto lesivo para los funcionarios del Estado encargados de administrar justicia, pues no existía por aquel entonces una clara delimitación funcional ni estructural entre la Administración Pública y la Administración de Justicia, controladas ambas por el poder regio ${ }^{35}$.

Los antecedentes más significativos del soborno deben buscarse en el sistema jurídico de la codificación española que tipificaba el delito de cohecho. Su evolución y también degeneración, como unidad delictiva y como conjunto de todos los elementos objetivos y subjetivos que separadamente lo componen, se debe a la adaptación legislativa en los tiempos políticos, económicos y sociales de la actualidad.

${ }^{34}$ J. Sainz GuerRA, La evolución histórica del Derecho penal español, Jaén, Servicio de Publicaciones e Intercambio de la Universidad de Jaén, 2004, p. 514, haciendo referencia a las obras de Graciano, Valentiniano y Teodosio (378-392 d. C.).

35 Ibid., pp. 514-515. 
Los distintos Códigos Penales que se han ido sucediendo en la historia de España han regulado el cohecho de forma sensiblemente diferente.

El Código Penal (CP) de 1822 incluía el delito de cohecho bajo el título «De los sobornos, cohecho y regalos que se hagan a los que ejercen algún empleo o cargo público» ${ }^{36}$.Una rúbrica muy extensa en la que tenían cabida numerosas y diversas conductas tendentes a sobornar, de una u otra manera, a los funcionarios como colectivo. El CP de 1848 respeta el criterio seguido por el Código anterior, con la particularidad de que si el cohecho hubiera sido un medio para cometer además prevaricación, la pena por ambos delitos se acumulaba, fundamento que posteriormente utilizaron los Códigos de 1850 y 1870, respectivamente. Sin embargo, el texto legal de 1848 opta por no sancionar de la misma manera al sobornante que al sobornado, diferencias que el legislador del actual Código también recoge. El CP de 1870 incluye por primera vez la posibilidad de que el funcionario reciba la dádiva o promesa mediante la participación de un tercero o persona intermedia. Pero habrá que esperar hasta el CP de 1995 para que se admita en el tipo que la dádiva o presente puede resultar en provecho de terceras personas. La regulación del CP de 1928 es la que más novedades presenta. Introduce un número considerable de tipos penales encaminados a luchar contra la corrupción en la Administración. Sin embargo, la regulación resulta en este Código mucho más benévola con el particular que con el funcionario, es más, el legislador eximía de responsabilidad al particular en el supuesto de que, aun habiendo sido suya la iniciativa, el funcionario aceptase el soborno, sin necesidad de que hubiera llegado a recibir la dádiva o a materializarse la promesa. Contrasta mucho la prolija regulación del cohecho en este CP de 1928 con la brevedad y concisión con que lo trataba, en cambio, el CP de 1848. Y sorprende ver cómo después de éste, con marcado deterioro de la técnica legislativa, la regulación del cohecho ha ido creciendo en extensión y complicación. Algunos autores como Luzón Cuesta ven precisamente en el CP de 1848 el punto de partida, o al menos el origen, de la regulación sistemática y de la denominación actual, pues antes se denominaba simplemente soborno, y mucho antes aún podemos encontrar el origen de este tipo en la «baratería» ${ }^{37}$. Otra reforma especialmente trascendente fue la operada en 1944. Este CP fue el primero que castigó la conducta del funcionario, cuando era él pre-

36 J. López Barja de Quiroga, L. Rodríguez Ramos y L. Ruiz de Gordejuela López, Códigos Penales españoles. Recopilación y concordancias, Madrid, Akal, 1988, p. 106.

${ }^{37}$ J. M. Luzón Cuesta, Compendio de Derecho penal. Parte especial, 12. ${ }^{a}$ ed., Madrid, Dykinson, 2004, p. 283. 
cisamente quien tomaba la iniciativa de cara a conseguir un acuerdo constitutivo de cohecho.

Todos los Códigos anteriores tan sólo penaban al funcionario que aceptase el ofrecimiento de un particular. Ello ha supuesto un importante trastoque de la clasificación que la doctrina hacía de los distintos tipos de cohecho $^{38}$, pero, sobre todo, se han adelantado las barreras punitivas a los momentos anteriores a alcanzar el acuerdo entre las dos partes para cometer el cohecho, porque al aceptarse típicamente tanto la solicitud del funcionario como la oferta del particular, el delito se consuma con la verificación de cualquiera de tales conductas ${ }^{39}$.

El CP de 1973 regulaba, como especialidad respecto de los anteriores (y a su vez con influencia en el actual CP), la atipicidad de la conducta de quien ofrecía dádiva a un funcionario en consideración a su función ${ }^{40}$, completándose todas las formas de cohecho con la regulación de la LO 9/1991, de 22 de marzo ${ }^{41}$, la cual introdujo el término dádiva junto con el de regalo. Asimismo resulta relevante mencionar que se regula el decomiso de las dádivas o presentes ${ }^{42}$.

Actualmente, el cohecho viene regulado en los arts. 419 a 427 del CP vigente de 1995, ocupando el capítulo V del título XIX y rubricado «Delitos contra la Administración Pública» del libro II. Los arts. 419, 420, 421, 425 y $426 \mathrm{CP}$ incluyen las distintas conductas que pueden dar origen a un cohecho cometido por funcionario público. Por el contrario, las conductas típicas en las que puede incurrir un particular vienen contempladas de forma mucho más escueta, registradas en los dos apartados del art. $424 \mathrm{CP}$. Desde la perspectiva sistemática no resulta apropiado separar en artículos no consecutivos las conductas que hacen referencia a un mismo sujeto activo e intercalar entre ellos conductas propias de otros sujetos. El art. $423 \mathrm{CP}$ extiende lo dispuesto en los tres artículos anteriores a los jurados, árbitros, peritos o cualesquiera personas que participen en el ejercicio de la función pública. La ubicación sistemática de este precepto hace que los casos tipi-

${ }^{38}$ El delito de cohecho comenzó clasificándose como un delitos bilateral o de participación necesaria, hasta que el castigo del particular por tomar la iniciativa corrupta frente al funcionario público supuso que se clasificara como un delito autónomo, penándose por separado la conducta del particular y la del funcionario público.

39 I. Valeije Áldvarez, El tratamiento penal de la corrupción del funcionario: el delito de cohecho, Madrid, Edersa, 1996, p. 38.

40 Arts. 390 y 391 CP 1973.

${ }^{41}$ LO 9/1991, de 22 de marzo, por la que se modifican los arts. 367, 368 y 390 CP y se introduce un nuevo capítulo acerca del tráfico de influencias.

${ }_{42}$ Art. 393 CP 1973. 
ficados en los arts. 426 y $427 \mathrm{CP}$, que también se refieren a los funcionarios públicos, no sean aplicables a esta serie de sujetos. Tal opción responderá a cuestiones de política legislativa difícilmente comprensibles desde la realidad de estos tipos penales. Algo similar ocurre con la ubicación sistemática del art. 424 CP (cohecho cometido por particular) que, en buena lógica, podría ir relacionado con las tres modalidades del cohecho de funcionario que le anteceden, y que produce, en cambio, que no sea aplicable a los casos de los arts. 425 y $426 \mathrm{CP}^{43}$. La exención de responsabilidad criminal del particular que denunciare al funcionario público que le hubiere solicitado dádiva o presente se recoge en el art. 426 CP. Se trata de una novedad del Código Penal de 1995, fundamentada en razones de política criminal a fin de favorecer y facilitar la persecución de tales delitos ${ }^{44}$; ello ha sido objeto de numerosas críticas. Se cierra el capítulo con el art. 427, que define a los funcionarios públicos extranjeros y aquéllos de la Unión Europea (UE).

Dicho capítulo destaca por la infortunada técnica legislativa desplegada, puesta de manifiesto en un exceso de artículos, en su deficiente ordenación sistemática y en la utilización de un lenguaje y unos términos poco precisos. Todo lo cual contribuye a obstaculizar la regulación y tipificación del cohecho en el sector privado y, por ende, el cohecho internacional, pues aunque se trate de corrupción en los negocios y dentro del sector privado, el sustrato de la conducta y de los elementos típicos coincide en esencia con el delito de cohecho.

Cabe ampliar esta exposición afirmando que las posturas doctrinales más radicales se caracterizaron por defender una autoregulación como forma de reducir el soborno en el sector privado, pero incluso esta corriente minoritaria ha terminado por admitir que debe ser igualmente la ley, en última instancia, la que ha de garantizar un marco legal para su prevención y, en su caso, punición ${ }^{45}$. En esta línea, y para contrarrestar la impunidad de algunos sobornos trasnacionales, se intentó dar mayor peso al soft law ${ }^{46}$ de origen

${ }^{43}$ En este sentido vid. M. J. ROdRíguez PuerTA, «La responsabilidad del particular en el delito de cohecho. Comentarios de la Sentencia del Tribunal Supremo de 29 abril 1998», Revista de Derecho y Proceso Penal, núm. 1 (1999), pp. 198-199.

${ }^{44}$ E. Bacigalupo Zapater, Curso de Derecho penal económico, 2. ${ }^{a}$ ed., Madrid, Ediciones Jurídicas y Sociales, 2005, p. 688.

45 G. Heine y T. Rose, Private Commercial Bribery (A Comparision of National and Supranational Legal Structures), Freiburg, Max Planck-Institut, 2003, pp. 1-21, disponible en http://www.peacepalacelibrary.nl/ebooks/files/FAPrivate_Bribery.pdf.

${ }^{46}$ La expresión doctrinal soft law aún no ofrece contornos precisos; hace referencia a un método normativo de interés público empleado en el Derecho internacional como un conjunto de instrumentos que en principio carecen de rango normativo en sentido conven- 
privado y público ${ }^{47}$, así como a la armonización del derecho de los negocios procedentes de organizaciones internacionales. Las normas que se plasman en las políticas de empresa (corrupción, competencia, reglamentos internos en el ámbito del mercado de valores, programas de compliance) son mixtas en su contenido público-privado y en su génesis estatalsupraestatal; de ahí los programas anticorrupción, cuyo origen se asienta casi siempre sobre el delito de cohecho. A esta normativa se deben añadir los estándares anticorrupción que han ido publicando diversas organizaciones internacionales, tanto el Banco Mundial y numerosas organizaciones intergubernamentales como Transparencia Internacional (TI). Pero, en definitiva, cada empresa construye su propia política anticorrupción y determina las prohibiciones, las cuales, a fin de cuentas, proceden de los Códigos Penales ${ }^{48}$.

Nuevamente hay que repetir que la corrupción ha sido un asunto de funcionarios públicos o políticos ímprobos que se aprovechaban de su cargo para vender funciones públicas o que incluso extorsionaba a los particulares, haciéndoles pagar por los servicios públicos que habían de prestar.

A partir de su origen y hasta la actualidad, la comisión del delito de cohecho trasnacional ha adquirido unas considerables proporciones en relación a su casuística, pues desde las compras de los entes gubernamentales en unidades y términos monetarios hasta su expansión en el sector privado, muy a menudo la raíz se encuentra en la creciente competencia desleal y en la globalización, y a ello deben hacer frente las empresas y comercios pequeños y medianos. Asimismo, el hecho de la globalización ha propiciado adicionalmente el desarrollo de nuevas figuras corruptas. La liberalización de los mercados ha facilitado que los agentes con poder adquisitivo aumentaran de forma muy significativa sus beneficios y su poder de influencia económica en las políticas.

Dadas las presiones internacionales mencionadas, los nuevos delitos de corrupción se inscriben en el proceso de armonización legislativa del Derecho penal español, cuya tendencia es la de avanzar hacia un Derecho penal único, motivo por el cual resulta fundamental analizar la normativa precedente y actual del delito de cohecho.

cional, que no han sido creados por instituciones dotadas de poder legislativo, pero que adquieren relevancia jurídica.

${ }^{47}$ M. Muñoz de Morales Romero, El legislador penal europeo: legitimidad y racionalidad, Madrid, Civitas, 2011, p. 7.

${ }^{48}$ L. Arroyo Zapatero y A. Nieto Martín, El Derecho penal económico..., op. cit., pp. 13-14. 
La ratificación por España del Convenio de la $\mathrm{OCDE}^{49}$ y las propuestas europeas de lucha contra la corrupción política, económica y comercial obligó a España a adaptar la regulación del soborno transnacional a las nuevas formas de criminalidad organizada o empresarial con un agente público extranjero: los delitos de corrupción en las transacciones comerciales internacionales. La incorporación en el CP de 1995 tuvo lugar primeramente a través de la LO 3/2000, de 11 de enero ${ }^{50}$, sucediéndose posteriores reformas legislativas que afectaban a este injusto mediante la LO 15/2003 y la LO 5/2010, y, por último, la reforma la LO 1/2015, que los ubicó en el título XIII del libro II del CP relativo a los delitos socioeconómicos. Estos delitos han sido el resultado de una evolutiva regularización en el ámbito internacional y europeo contra la creciente corrupción de los agentes públicos extranjeros.

\section{COMPROMISOS INTERNACIONALES Y NACIONALES PARA COMBATIR EL COHECHO TRANSNACIONAL}

En las últimas décadas ha aumentado la preocupación internacional por la expansión e incidencia de la corrupción en la vida política, económica y social, y se ha tratado de combatir con la promulgación de directrices, normativas y convenios impulsados y aprobados en el seno de las organizaciones internacionales. El delito de corrupción en el tráfico económico internacional se integró como hecho típico en el CP español a raíz de los compromisos internacionales adquiridos, los cuales evidencian el desarrollo normativo internacional en este tema y ponen de manifiesto la creciente preocupación trasnacional por la corrupción económica y comercial.

Las propuestas de persecución de la llamada corrupción internacional han surgido desde diversas instituciones extranjeras internacionales. El marco institucional y el horizonte político de cada una de ellas varía y de ahí que la eficacia de los respectivos instrumentos normativos en la lucha contra la corrupción transnacional también resulte diferente, si bien están

${ }^{49}$ Convenio de lucha contra la corrupción de agentes públicos extranjeros en las transacciones comerciales internacionales aprobado por la OCDE.

${ }^{50}$ Introducción por LO 3/2000 como consecuencia directa del Convenio de lucha contra la corrupción de agentes públicos extranjeros en las transacciones comerciales internacionales aprobado por la OCDE en 1997. La ratificación por España de dicho Convenio ha revestido una notable relevancia; tuvo lugar mediante instrumento depositado el 4 de enero de 2000 (BOE de 22 de febrero de 2002), aunque el mismo Convenio preveía de forma general su entrada en vigor el 15 de febrero de 1999. 
inspirados unos en otros. Las distintas normas internacionales regulan objetos de protección muy diversos, aunque todos relacionados: la libre competencia en el comercio internacional y la protección de la función pública extranjera a imagen y semejanza de la protección de la Administración interna de cada país ${ }^{51}$.

\section{Iniciativas normativas internacionales}

Como ya ocurrió en otras ocasiones a lo largo de nuestra historia más reciente y ante el hecho real de preocupación transnacional, fueron los Estados Unidos los que tomaron la iniciativa para implantar directrices y códigos de conducta de prevención de la corrupción. Frente a la plaga de la corrupción, cuya expansión creció desmesuradamente con el capitalismo y la globalización, se dictó la Foreign Corrupt Practices Act en 1977 $(\mathrm{FCPA})^{52}$. Y aunque esta Ley no tuvo trascendencia internacional, sí fue un texto pionero para combatir y atajar la corrupción y corrosión de los intereses públicos. La FCPA significó una verdadera línea precursora para la lucha contra la corrupción y esbozó, entre otros conceptos que con posterioridad adquirirían gran importancia, el principio de la territorialidad, el cual quedó definido de manera pormenorizada para la persecución de las conductas corruptas. Todos aquellos actos corruptos realizados en los Estados Unidos a través de transacciones electrónicas o de intermediarios, transmisiones telefónicas o facsímiles e incluso viajes internacionales, serían susceptibles de enjuiciarse conforme a la FCPA.

En el año 1996 la Organización Mundial de Comercio (OMC) desempeñó un papel muy activo en la redacción y el impulso de las Recomendaciones de la Convención Interamericana contra la Corrupción, adoptada en Caracas el 29 de marzo de 1996 (CICC). En las mismas, la extorsión y el cohecho constituyeron claramente los factores determinantes en la distorsión del mercado internacional ${ }^{53}$. La Convención tuvo por finalidad actuar como medio para frenar los desmanes de la corrupción y la irresponsabili-

51 M. Cugat Mauri, «La corrupción de las transacciones comerciales internacionales», en M. GarCía ArÁn (ed.), El fenómeno de la internacionalización de la delincuencia económica, Estudios de Derecho judicial, núm. 61 (2004), pp. 328-329.

52 Ley de prácticas corruptas en el extranjero, disponible en http://www.justice.gov/ criminal-fraud/foreign-corrupt-practices-act.

53 Las Reglas de Conducta de la CCI para combatir la extorsión y el cohecho, adoptadas por el Comité Ejecutivo de la CCI el 26 de marzo de 1996, no precisan cambios. La CCI publicó en 1999 un manual que incluía las mejores prácticas empresariales para acom- 
dad pública, si bien la actualidad contradice la estela de su eficacia a pesar de sus benévolos propósitos.

En este contexto de preocupación internacional en la lucha contra la corrupción se promulgó el Convenio para combatir el cohecho a funcionarios públicos extranjeros en las transacciones comerciales internacionales de la OCDE. La aprobación de la Recomendación sobre la lucha contra la corrupción en las transacciones comerciales internacionales, adoptada por el Consejo de la OCDE el 23 de mayo de 1997, revistió una importancia crucial que, entre otras cuestiones, reclamaba medidas eficaces para la disuasión, la prevención y la lucha contra la corrupción de agentes públicos extranjeros en relación con las transacciones comerciales internacionales y, en particular, la tipificación como delito de dicha corrupción de forma eficaz. Se coordinaron dichas actuaciones conforme a los principios jurisdiccionales y jurídicos de cada país firmante ${ }^{54}$. La Convención estipula que la legislación en la que se tipifique como delito penal el cohecho de un funcionario público deberá ser aplicable a todas las personas tanto físicas como jurídicas, y deberá abarcar también el ofrecimiento o promesa de la entrega de cualquier dádiva constitutiva de soborno. Se penará como un delito autónomo, con independencia de que la conducta típica se realice mediante intermediario y el beneficiario sea un funcionario público extranjero o un tercero. Igualmente habrán de prohibirse todas las formas de cohecho, incluidas las ventajas tangibles o intangibles y las pecuniarias o no pecuniarias. El Convenio tiene también por objeto, además de sancionar el cohecho sobre transacciones comerciales internacionales, castigar cualesquiera otras ventajas ilícitas en los negocios, lo que a su vez puede implicar la obtención de contratos a nivel internacional y cualquier tipo de permisos reglamentarios o tratos preferentes en materia fiscal o aduanera, así como en procedimientos judiciales o incluso también legislativos. Este

pañar las Reglas de Conducta y para ofrecer una guía para el cumplimiento del Convenio de la OCDE, Fighting Bribery, publicación CCI núm. 610.

${ }^{54}$ El 17 de diciembre de 1997 se acordó definitivamente en París el Convenio para combatir el cohecho a funcionarios públicos extranjeros en las transacciones comerciales internacionales. Dicho Convenio ha sido suscrito por 48 países, y las resoluciones correspondientes fueron previamente acordadas y recomendadas por la ONU, el Banco Mundial, el Fondo Monetario Internacional, la Organización Mundial de Comercio, el Consejo de Europa y la UE, además de contar con la colaboración de distintas compañías, organizaciones de negocios, sindicatos y organizaciones no gubernamentales. Resultaba, pues, evidente que para alcanzar un cierto progreso en el campo de la lucha contra la corrupción se precisaban no sólo esfuerzos a nivel nacional, sino también la cooperación multilateral. Vid. Convenio para combatir el cohecho a funcionarios públicos extranjeros en transacciones comerciales internacionales de 17 de diciembre de 1997 (Preámbulo). 
documento internacional fue un punto de referencia de suma importancia en la cooperación internacional para reprimir el cohecho y la corrupción ${ }^{55}$. Y ello gracias a que incluye igualmente normas de carácter no penal sobre la prevención, transparencia global y cooperación entre países. El Convenio de la OCDE actuó como una especie de Ley de Bases para el posterior Acuerdo adoptado en el seno europeo relativo a la lucha contra los actos de corrupción en los que estuvieran implicados funcionarios de las Comunidades Europeas o de los Estados miembro de la Unión Europea ${ }^{56}$, y ratificado a su vez por el Estado español.

Al hilo de lo anterior surgió también la Convención de la Unión Africana para Prevenir y Combatir la Corrupción, adoptada en julio 2003 y creada para fortalecer las leyes contra la corrupción en el continente africano. El valor del Convenio de la Unión Africana debe buscarse en la intencionalidad de los países que lo aprobaron y que no estaban representados en otros organismos internacionales, los cuales habían confeccionado varias iniciativas legislativas internacionales en la lucha contra la corrupción, como ya se ha indicado antes. No obstante, el cumplimiento y aplicación del Convenio africano no ha sido suficiente ni riguroso, ya que los índices de corrupción en la mayoría de los países africanos continúan siendo los más elevados, de acuerdo con las estadísticas de TI en los últimos años ${ }^{57}$.

Como consecuencia de la trayectoria internacional analizada en el marco del elenco de instrumentos multilaterales encaminados a prevenir y combatir la corrupción ${ }^{58}$ nació en el seno de la ONU la Convención de las

55 Por primera vez, las mayores empresas comerciales y de inversión del mundo, que en total representan más de un 70 por 100 del comercio mundial y el 90 por 100 de la inversión extranjera directa, actuaron de forma acorde para intentar detener el flujo de sobornos a funcionarios públicos extranjeros en las transacciones comerciales internacionales. Vid. Convención OCDE 1997, síntesis de política de la OCDE elaborada por la División de Asuntos Públicos, Dirección de Asuntos Públicos y Comunicados, publicados bajo responsabilidad del secretario general por L'Observateur de la OCDE en julio de 2004, disponible en https://www.observateurOCDE.org y https://www.oecd.org.

56 Diario Oficial de las Comunidades Europeas (DOCE), núm. 195, de 25 junio de 1997 (Documento 497AO 625), ratificado por España el 30 de noviembre de 1999.

57 Resultados de los índices globales de corrupción de 2013, disponibles en http://cpi. transparency.org/cpi2013/results/ (20 de agosto de 2014), situándose Somalia en el puesto más alto, seguido de Sudán y Libia, e intercalado por Afganistán y Corea del Norte.

${ }^{58} \mathrm{La}$ ONU reconoció los siguientes instrumentos multilaterales como inspiración para acordar la Convención: la Convención Interamericana contra la Corrupción, aprobada por la Organización de los Estados Americanos el 29 de marzo de 1996; el Convenio relativo a la lucha contra los actos de corrupción en los que estén implicados funcionarios de las Comunidades Europeas o de los Estados miembros de la Unión Europea, aprobado por el Consejo de la Unión Europea el 26 de mayo de 1997; el Convenio sobre la lucha contra el soborno de los funcionarios públicos extranjeros en las transacciones comerciales internacionales, 
Naciones Unidas contra la Corrupción (UNCAC), también conocida como la Convención de Mérida, cuyo origen se sitúa en la Oficina de las Naciones Unidas contra la droga y el delito, y que entró en vigor en diciembre $2005^{59}$. Este documento, junto con el Convenio de la OCDE, representan los instrumentos internacionales más significativos para España en la lucha contra la corrupción. Los Estados miembros ${ }^{60}$ confeccionaron la UNCAC para paliar la preocupación por la gravedad de los problemas y amenazas que planteaba la corrupción de cara a la estabilidad política y a la seguridad civil y ciudadana de las sociedades, puesto que socava las instituciones y los valores de la democracia, la ética y la justicia. En ese panorama de inquietudes, la citada Convención pretendió implantar un sistema de cooperación internacional para la erradicación de la corrupción a través de un enfoque multidisciplinar, al quedar bien entendido que el enriquecimiento personal ilícito puede ser particularmente nocivo para las instituciones democráticas, las economías nacionales y el imperio de la ley ${ }^{61}$. La UNCAC mejora considerablemente el alcance de la Convención de la OCDE y aglutina, de forma más compacta, instrumentos como la penalización de la extorsión a los funcionarios públicos ${ }^{62}$.

Todos los instrumentos normativos internacionales anteriormente analizados configuran la naturaleza social, jurídica y económica en la que ha de interpretarse el injusto de la corrupción en las transacciones comerciales internacionales dentro del Derecho penal español. Los antecedentes internacionales influyen de forma indirecta, aunque significativa, en la delineación de un tipo de soborno pluriofensivo.

aprobado por la OCDE el 21 de noviembre de 1997; el Convenio de Derecho penal sobre la corrupción, aprobado por el Comité de Ministros del Consejo de Europa el 27 de enero de 1999; el Convenio de Derecho civil sobre la corrupción, aprobado por el Comité de Ministros del Consejo de Europa el 4 de noviembre de 1999; la Convención de la Unión Africana para Prevenir y Combatir la Corrupción, aprobada por los jefes de Estado y de Gobierno de la Unión Africana el 12 de julio de 2003, y, por último, partiendo de las bases jurídicas que dispuso la Resolución 55/25, la Convención de las Naciones Unidas contra la Delincuencia Organizada Transnacional.

59 La Convención de las Naciones Unidas contra la Corrupción (UNCAC), también conocida como la Convención de Mérida por haber sido adoptada en esa ciudad de México, entró en vigor el 14 de diciembre de 2005 al reunir las treinta ratificaciones requeridas. Actualmente está integrada por 126 Estados miembros y fue ratificada en España y publicada en el BOE, núm. 171, julio de 2006. Disponible en bttp://www.programaanticorrupcion.gob. $m x$ (24 de agosto de 2014).

${ }^{60}$ Países miembros: 171; adhesión y ratificación: 140 países. Disponible en bttp://www. unodc.org/unodc/en/treaties/CAC/signatories.btml.

${ }_{61}$ Preámbulo de la UNCAC, Nueva York, 2004.

${ }^{62}$ Art. 15 de la Convención de Mérida. 


\section{Iniciativas normativas en la Unión Europea}

La corrupción afecta con mayor o menor grado de intensidad a cada uno de los países de la UE. Los perjuicios han sido, y son, nefastos a nivel financiero y social, ya que han ido minando la confianza de los ciudadanos en las instituciones democráticas.

La lucha contra la corrupción viene siendo, sin duda, uno de los objetivos prioritarios en la UE, aunque no existe un Derecho penal propio de la UE. El propio Tratado de la Unión Europea (TUE) contiene una mención expresa sobre la lucha contra la corrupción. Una de las premisas para lograr combatir de forma real y eficaz ésta se centra en la cooperación judicial y política de los países europeos.

En paralelo a las primeras iniciativas internacionales para luchar contra la corrupción, en la Unión Europea se fue despertando una destacada preocupación por atajar la materia, bien entendido que, al principio, las consecuencias de la corrupción se circunscribían sólo al ámbito económico.

Inicialmente, el Acto del Consejo Europeo de 26 de julio de 1995 confeccionó el Convenio relativo a la protección de los intereses financieros de las Comunidades Europeas ${ }^{63}$. La protección de estos intereses frente a la corrupción quedó preservada en el Protocolo del Convenio de 26 de julio de 1995, relativo a la protección de los intereses financieros de las Comunidades Europeas (convenio de la UE) ${ }^{64}$. Este protocolo hizo especial hincapié en la definición de los conceptos de funcionario y corrupción activa y pasiva, así como en la armonización de las sanciones para los delitos de corrupción, pero quedó casi sin efecto cuando se adoptó el Acto el 26 de mayo de 1997, mediante el cual quedó aprobado el Convenio relativo a la lucha contra los actos de corrupción en los que estuvieran implicados funcionarios de las Comunidades Europeas o de los Estados miembros de la $\mathrm{UE}^{65}$.

${ }^{63}$ DOCE, núm. 316, de 27 de noviembre de 1995.

${ }^{64}$ DOCE, núm. 313, de 23 octubre de 1996. Protocolo establecido, sobre la base del art. K3 del Tratado de la UE, del Convenio relativo a la protección de los intereses financieros de la CCEE de 27 de septiembre de 1996, que entró en vigor de forma general y para España el 17 de octubre de 2002 (BOE, núm. 233, de 29 de septiembre de 2003, tras la oportuna corrección de errores).

${ }^{65}$ Acto del Consejo de Europa de 26 de mayo de 1997, adoptado en aplicación del Título VI del Tratado de la Unión Europea 97/C 195/01. Se estableció sobre la base de la letra c) del apartado 2 del art. K.3 del Tratado de la Unión Europea, el Convenio relativo a la 
En aquel momento, el enfoque de la corrupción hacía referencia principalmente al desarrollo institucional de la Unión Europea y sus países miembros, es decir, en lo que respecta a la transparencia, el control de las cuentas obtenidas en programas públicos y a la intención de crear organismos autónomos para la lucha contra la corrupción.

El Convenio penal sobre la corrupción de 27 de enero de 1999 de Estrasburgo ${ }^{66}$, confeccionado por el Consejo de Europa, entró en vigor para la UE en el 2002, sin perjuicio de la necesaria, posterior y paulatina ratificación de cada Estado miembro. Igualmente fue ratificado por la UE el Convenio civil sobre la corrupción de 4 de noviembre de 1999 de Estrasburgo ${ }^{67}$, emitido en el Consejo de Europa.

El objetivo principal de la ratificación del Convenio penal de Estrasburgo (Convenio del Consejo) fue el resultado del anhelo de que los Estados tipificasen como delitos una serie de conductas corruptas, entre ellas el cohecho activo y pasivo en el sector público y en el privado, además del tráfico de influencias, el blanqueo de productos del delito de corrupción y los delitos contables. Podría decirse que el Convenio del Consejo es mucho más amplio que los anteriores documentos supranacionales contra la corrupción en lo que respecta al número de conductas que exigió tipificar como delito.

A principios del año 2000, en Europa ya se habían delimitado formas típicas y concretas de los nuevos delitos de corrupción. Las bases para la regulación en cada Estado del delito de corrupción en las transacciones internacionales comerciales habían quedado fijadas.

Con el Tratado de Lisboa de 13 de diciembre de 2007, sin perjuicio de haber suprimido el tercer pilar de la UE procedente del Tratado de Roma, se intentó que se sometiesen todas las normas relativas a justicia y seguridad al control del Tribunal de la Unión Europea. Se pretendió establecer medidas cada vez más armonizadoras; no obstante, en materia de corrupción la mayoría de tales medidas fueron acordadas mediante decisiones marco, no directivas o reglamentos que poseen un alcance obligatorio y coercitivo mayor para todos los Estados miembros. Si el control sobre las

lucha contra los actos de corrupción en los que estén implicados funcionarios de las Comunidades Europeas o de los Estados miembro de la Unión Europea.

${ }^{66}$ El Convenio núm. 173 del Consejo de Europa entró en vigor de forma general el 1 de julio de 2002 y fue ratificado por España el 28 de abril de 2010 (BOE, núm. 182, de 28 de julio de 2010), entrando en vigor el 1 de agosto de 2010.

${ }^{67} \mathrm{El}$ Convenio núm. 174 del Consejo de Europa fue ratificado el 16 de diciembre de 2009 (BOE, núm. 78, de 31 de marzo de 2010) y entró en vigor el 1 de abril de 2010. 
medidas contra la corrupción no comienza en los ámbitos locales y nacionales, ninguna eficacia real tendrá la jurisdicción y el ius puniendi del Tribunal de Justicia de las Comunidades Europeas, al cual, aún hoy día, no se le han atribuido competencias concretas sobre los delitos de corrupción. El Tratado de Lisboa facilitó el reconocimiento mutuo de resoluciones judiciales y unificó ciertas infracciones relativas a delitos con dimensión transfronteriza, además de otros de especial gravedad ${ }^{68}$.

Las tendencias armonizadoras de la UE dentro del Derecho penal y en relación con la corrupción concluyen en la tipificación unánime del eurodelito de corrupción en las transacciones comerciales internacionales con agentes públicos extranjeros, delito que deberá ser enjuiciado y castigado en los tribunales de cada país.

\section{Ratificación de España de los documentos internacionales y evaluación de su trasposición en la lucha contra la corrupción de los delitos de corrupción en las transacciones comerciales internacionales}

Toda la proliferación normativa internacional comprometió a España a desarrollar una reglamentación interna para prevenir la corrupción en el sector público y privado, así como la posible trascendencia internacional de los fraudes en ambos sectores.

Como consecuencia de las iniciativas internacionales brotó la inevitable necesidad de proveer de un impulso político a la lucha contra la corrupción desde España. Ello supuso la asunción y adaptación de las corrientes internacionales con el fin de dar cumplimiento a los compromisos internacionales ex arts. 94 y 96 de la Constitución. Los intentos patrios por intentar combatir la corrupción a través de un enfoque multidisciplinar continúan en pie; sin embargo, no son suficientes y la forma de su ejecución tampoco es la adecuada.

España ha cumplido con la ratificación de todos los convenios y documentos internacionales o comunitarios de los que forma parte. Los más relevantes y con influencia directa para el análisis penal del cohecho internacional son: el Convenio de la OCDE, el más significativo en la lucha

${ }^{68}$ Arts. 82 y 83 del Tratado de Funcionamiento de la UE, Reglamento (UE) núm. 267/2010 de la Comisión, de 24 de marzo de 2010, relativo a la aplicación del art. 101, apartado 3. Tratado de Roma, 1957. 
contra la corrupción de agentes públicos extranjeros en las transacciones comerciales internacionales, seguido, en cuanto a orden de importancia, por la UNCAC ${ }^{69}$; el Convenio relativo a la protección de los intereses financieros de las Comunidades Europeas (CCEE), así como sus dos Protocolos adicionales, junto con el Convenio relativo a la lucha contra los actos de corrupción en los que estén implicados funcionarios de las CCEE o de los Estados miembros de la UE, y, por último, el Convenio del Consejo de Europa.

A partir del Convenio de la OCDE y de las propuestas europeas surgió la ineludible necesidad en España de adaptar la regulación de forma más amplia a los tipos de cohecho. Fruto de lo anterior nació dentro de este mismo título XIX su último capítulo $\mathrm{X}$, «De los delitos de corrupción en las transacciones comerciales internacionales», novedosa incorporación en el CP de 1995 que sustituía al antiguo art. 445 bis introducido por LO 3/2000, de 11 de enero ${ }^{70}$, que a su vez fue modificado y redactado de nuevo por la LO 15/2003 ${ }^{71}$. La introducción de este tipo delictivo de cohecho como un delito independiente contra la Administración Pública se debió a la evolución de la normativa a nivel europeo e internacional, de la cual España no pudo despreocuparse por estar inmersa en la dinámica de la creciente corrupción que fue superando el ámbito estrictamente nacional. La LO 5/2010 72 reformó nuevamente el delito analizado, introduciendo la posibilidad de que se cometiese por personas jurídicas y previendo las correspondientes sanciones. No hay que olvidar que el delito de cohecho transnacional ha sido el resultado de una evolutiva regularización en el ámbito internacional y europeo contra la creciente corrupción de los agentes públicos extranjeros. La última reforma del CP por LO 1/2015, sin embargo, ha trasladado estos delitos al sector privado y a la corrupción en los negocios, ubicados en el art. 286 ter, dentro de la sección 4. ${ }^{a}$ del capítulo XI del título XIII relativo a los delitos contra el orden socioeconómico.

Han sido cuatro las reformas en el CP que han afectado al delito de cohecho trasnacional; en ello se ha traducido, a modo de fiel reflejo de la evolución legislativa y de la creciente repulsa social experimentada en

${ }^{69}$ En relación con la UNCAC, también debe tenerse presente el Instrumento de ratificación de la Convención de las Naciones Unidas contra la delincuencia organizada transnacional, hecho en Nueva York el 15 de noviembre de 2000, ratificado el 13 de diciembre del 2000 por España y publicado en el BOE, núm. 233, de 29 de septiembre de 2003.

${ }^{70} \mathrm{LO} 3 / 2000$ que reformó el CP como consecuencia del Convenio de la OCDE en 1997 , ratificado por España en 2000

${ }^{71}$ LO 15/2003, de 25 de noviembre (BOE, núm. 283, de 26 de noviembre de 2003).

72 LO 5/2010, de 22 de junio (BOE, núm. 152, de 23 de junio de 2010). 
España respecto a este tipo de corrupción. También han tenido una incidencia indiscutible las recomendaciones y críticas que recibió España por parte de los grupos de trabajo de la OCDE sobre la regulación de este delito y la trasposición del Convenio de la $\mathrm{OCDE}^{73}$. Además de las reformas del CP, han emergido otras reformas legislativas dignas de mención en materia de lucha contra la corrupción que vienen a colmar determinadas lagunas interpretativas en el ámbito penal.

En primer lugar, el proyecto inicial de la LO 3/2000 en materia de lucha contra la corrupción de agentes públicos extranjeros en las transacciones comerciales internacionales ${ }^{74}$, remitido por el gobierno a las Cortes Generales, optó al principio por la incorporación del Convenio de la OCDE mediante la introducción de un apartado $3 .^{\circ}$ en el art. $423 \mathrm{CP}^{75}$. La ubicación sistemática era, por tanto, el título XIX del libro II relativo a los delitos contra la Administración Pública, y más en concreto dentro del capítulo $\mathrm{V}$, relativo al cohecho. De dicha ubicación se podía desprender que el bien jurídico inicialmente protegido era la Administración Públi$\mathrm{ca}, \mathrm{y}$, por tanto, se extendían así a un plano supranacional los posibles sujetos que podían ser corrompidos. Como consecuencia de lo anterior, desde un sector parlamentario mayoritario se argumentó que la inclusión de este tipo delictivo se dirigía a proteger diversos bienes jurídicos: primeramente, el correcto funcionamiento de la Administración Pública y, en segundo lugar, el orden socioeconómico, la libertad y la lealtad de la competencia en las relaciones económicas internacionales. Dada la afinidad de esta conducta con los delitos de cohecho, se estimó conveniente insertarla entre los mismos, aunque se reconoció que no existía una identidad total del bien jurídico protegido ${ }^{76}$. Otro grupo parlamentario mino-

${ }^{73}$ Informes de la OCDE relativos a la implementación del Acuerdo firmado para la lucha contra la corrupción en España. Disponible en bttp://www.oecd.org/daf/anti-bribery/ spain-oecdanti-briberyconvention. htm.

${ }^{74}$ LO 3/2000, de 11 de enero, de modificación de la LO 10/1995, de 23 de noviembre, del CP, en materia de lucha contra la corrupción de agentes públicos extranjeros en las transacciones comerciales internacionales (BOE, núm. 10, de 12 de enero de 2000).

75 Antiguo art. 423: «1. Los que con dádivas, presentes, ofrecimientos o promesas corrompieren o intentaren corromper a las autoridades o funcionarios públicos serán castigados con las mismas penas de prisión y multa que éstos. 2. Los que atendieren las solicitudes de las autoridades o funcionarios públicos, serán castigados con la pena inferior en grado a la prevista en el apartado anterior».

76 Palabras del señor Arqueros Orozco del Grupo Parlamentario Popular, Cortes Generales, Diario de Sesiones del Congreso de los Diputados, Pleno y Diputación Permanente, VI Legislatura, año 1999, núm. 277, Sesión Plenaria núm. 267, celebrada el jueves 25 de noviembre de 1999, pp. 14965-14966: «Los bienes jurídicos consistentes en un correcto funcionamiento de la Administración y una conducta proba y legal de los funcionarios, se orienta 
ritario de senadores propuso la creación de un nuevo título con un nuevo art. 445 bis, al considerar que el bien jurídico protegido no era la Administración Pública, sino la lucha contra la corrupción en las transacciones comerciales internacionales. De ahí la necesidad de añadir un título nuevo con un artículo nuevo ${ }^{77}$. Finalmente quedó consolidado de esa manera, y ello motivó que se incluyera en la propia Exposición de Motivos, es decir, que el bien jurídico tutelado es la lucha contra la corrupción en las transacciones comerciales internacionales, el anterior art. 445 bis introducido por LO 3/2000.

En segundo lugar, la reforma del CP por la LO 15/2003 ${ }^{78}$, por su parte, incorporó el art. 445, recogiendo la redacción anterior del art. 445 bis e introduciendo el apartado $2{ }^{\circ}$ Se ubicó este artículo en el capítulo X dentro del título XIX, «De los delitos contra la Administración Pública», del libro II, Parte Especial, del CP. Dicha ubicación fue objeto de sumas críticas, porque, entre otras razones, y al igual que consideró Morillas Cueva ${ }^{79}$, la citada reforma trasladaba los contenidos de ese título XIX, sobre todo el núm. 1 del art. 445, sin perjuicio de la posible aplicación de la regla concursal del art. $444^{80}$. El legislador decidió finalmente encuadrar el art. 445 a continuación del capítulo IX, dedicado a las negociaciones y actividades prohibidas a los funcionarios públicos en

primordialmente a tutelar la libertad y lealtad de la competencia en las relaciones económicas internacionales, en particular, en la relación de los agentes económicos con las autoridades y funcionarios de terceros países, como ha indicado el Consejo de Estado en su dictamen. En este nuevo delito predomina teleológicamente la protección contra el ataque al orden socioeconómico, sin embargo, la estructura del mismo es similar a los delitos de cohecho. Es esta afinidad de los perfiles básicos de las figuras delictivas la que ha llevado a su inclusión dentro de las mismas, si bien no existe identidad total del bien jurídico protegido».

77 Palabras del señor Zubía Atxaerandio, Cortes Generales, Diario de Sesiones del Senado, VI Legislatura, año 1999, núm. 156, Sesión del Pleno celebrada el jueves 16 de diciembre de 1999, p. 7635. El Grupo Parlamentario Vasco (EAJ-PNV) en el Congreso ya intuía esta idea. Compárese la opinión de la señora Uría Echevarría, Cortes Generales, Diario de Sesiones del Congreso de los Diputados, Pleno y Diputación Permanente, VI Legislatura, año 1999, núm. 277, Sesión Plenaria núm. 267, celebrada el jueves 25 de noviembre de 1999 , p. 14963 , quien aludía a la tutela de «un cierto orden internacional en las transacciones económicas». En el mismo sentido se manifestaba el señor Guardans i Cambó del Grupo Catalán (Convergència i Unió), p. 14964, al señalar que sería conveniente introducir un título distinto dirigido a proteger como bien jurídico «el buen orden económico mundial o algo por el estilo».

${ }^{78}$ LO 15/2003, de 25 de noviembre, por la que se modifica la LO 10/1995, de 23 de noviembre, del Código Penal.

${ }^{79}$ L. Morillas Cueva, en M. Cobo del Rosal (coord.), Derecho penal español. Parte especial, 2. ${ }^{\text {a }}$ ed., Madrid, Dykinson, 2005, pp. 900 y ss.

80 Art. 444 CP: «Las penas previstas en el art. 443 se impondrán sin perjuicio de las que correspondan por los delitos contra la libertad sexual efectivamente cometidos». 
el ejercicio de sus funciones, y siguiendo la opinión de dicho autor, esta posición no era baladí, pues ponía de manifiesto la inclinación legislativa por situar de manera prevalente el bien jurídico protegido referido al ordenado funcionamiento de la Administración Pública, sin obviar, lógicamente, el tráfico comercial internacional ${ }^{81}$.

En tercer lugar, la regulación examinada adolecía de determinadas lagunas legislativas que no respondían a la literalidad e intención de los preceptos de la Convención de la OCDE. Se procedió, por tanto, a redactar de nuevo y de forma más rigurosa los elementos típicos del art. 445 mediante LO 5/2010 ${ }^{82}$. Esta reforma tuvo lugar con motivo de la trasposición de la Decisión Marco 2003/568/JAI relativa a la lucha contra la corrupción en el sector privado. La represión de los actos corruptos de los administradores de entidades privadas de forma similar al delito de cohecho determinó la reforma legislativa ${ }^{83}$. Se introdujo el art. 286 bis, comprensivo de la corrupción activa y pasiva entre particulares, tipificando así la conducta de quien ofrece, promete o concede un beneficio o ventaja a directivos, administradores, empleados o colaboradores de una empresa a fin de obtener un favor de ésta en el transcurso de la adquisición de venta de mercancías o prestación de servicios profesionales. Se trata de un delito que ataca la libre competencia del mercado en el sector privado. En dicho contexto se creó un nuevo subtipo de este injusto, incluido en el apartado $4 .^{\circ}$ del citado artículo, denominado la corrupción en el ámbito deportivo. Por último, dentro del art. 445 se encuadró la definición de funcionario público extranjero y de organizaciones internacionales. La redacción se asemejó a la enunciación autónoma que marcó el Convenio de la OCDE del agente público extranjero, sin perjuicio de que posteriores documentos internacionales y europeos acogieran tal definición con ciertas variaciones.

En cuarto y último lugar, la reforma por LO 1/2015 del CP ${ }^{84}$ se configura a raíz de la aclamada necesidad de ofrecer unas mejoras técnicas y un sistema penal más ágil y coherente, y conferir así, entre otros componentes, una respuesta más adecuada a la corrupción y a las nuevas formas de delincuencia económica. Gran parte de la reforma se halla también orien-

${ }^{81}$ L. Morillas Cueva, en M. Cobo del Rosal, Derecho penal español..., op. cit., p. 905.

${ }^{82} \mathrm{LO} 5 / 2010$, de 22 de junio, por la que se modifica la LO 10/1995, de 23 de noviembre, del CP (BOE, núm. 152, de 23 de junio de 2010).

${ }^{83}$ Exposición de Motivos del BOE, núm. 152, de 23 de junio de 2010.

${ }^{84}$ LO 1/2015 por la que se modifica la LO 10/1995, de 23 de noviembre, del CP (BOE, núm. 77, de 31 de marzo de 2015). 
tada a dar cumplimiento a los compromisos internacionales adquiridos por España ${ }^{85}$. En materia de corrupción privada con agentes públicos extranjeros, la trasposición de los delitos marcados por los instrumentos internacionales se formalizó en adición a las indicaciones del grupo de trabajo de la OCDE para mejorar la implantación y la aplicación de dicha regulación ${ }^{86}$. Lejos de las pautas ya indicadas, la LO 1/2015 asienta los delitos de corrupción en los negocios o de las transacciones comerciales internacionales en el nuevo art. 286 ter, dentro del título XIII, relativo a los «Delitos contra el patrimonio y el orden socioeconómico», del capítulo XI, relativo a su vez a los «Delitos contra el mercado y los consumidores», de la Sección 4. ${ }^{\mathrm{a}}$, denominada «De los delitos de corrupción en los negocios». El citado precepto se ubica a partir de esta reforma a continuación de la denominada corrupción entre particulares del art. 286 bis. En conexión con dicha reforma del nuevo art. 286 ter, igualmente se modifica el art. 427 CP relativo a la imputación de los delitos de cohecho a funcionarios públicos de la UE. Mediante la LO 1/2015 se incluye en el precepto 427 el concepto de funcionario público extranjero, extrayéndose del tipo que antes regulaba los delitos de corrupción en las transacciones comerciales internacionales. El art. 286 ter no contempla la definición de funcionario público extranjero, como sí lo hacía el anterior art. 445, pero remite al art. $427 \mathrm{CP}$ para conceptuar lo que típicamente ha de entenderse por agente público extranjero. Igualmente incorpora la posibilidad de que el soborno transnacional se cometa con un funcionario español, pues el propio art. 286 ter también remite al art. 24 CP. El hecho de que este nuevo precepto 286 ter se ubique dentro del capítulo relativo a la corrupción en los negocios, de igual modo determina la introducción de los elementos típicos de la ventaja o negocio que obtiene el particular tras sobornar al funcionario en el tráfico económico internacional.

Los instrumentos internacionales en materia de corrupción suscritos por España han sido numerosos, por ello interesa describir las valoraciones realizadas a España respecto del acierto, implantación y atajo de la corrupción con agentes públicos extranjeros en el tráfico económico internacional.

85 Exposición de Motivos de la LO 1/2015. Vid. también C. Manfroni, Soborno transnacional, Buenos Aires, Abeledo-Perrot, 1998: «no siempre hay que forzar la aplicación de viejos principios a una nueva situación...» (p. 46), en relación con el cambio de ubicación sistemática de los delitos de corrupción en las transacciones comerciales internacionales.

${ }^{86}$ Phase 3, Report on Implementing the OECD Anti-Bribery Convention in Spain, diciembre de 2012, disponible en http://www.oecd.org/daf/anti-bribery/Spainphase3reportEN.pdf. 
La normativa europea en esta materia se contiene en la regulación penal española, en concreto, en lo que se refiere a los tipos de soborno con funcionarios públicos de la UE. Puede incluso afirmarse que la regulación española es más amplia que lo que dictamina el Convenio de la UE, ya que no se limita sólo a la tutela de los intereses financieros de la UE, sino que acoge conductas de cohecho propio, impropio, antecedente y subsiguiente en relación con la corrupción activa y pasiva ${ }^{87}$.

Respecto a la vertiente internacional que excede las fronteras de la UE, el grupo de trabajo de la OCDE de cohecho internacional ${ }^{88}$ evaluó, tras la reforma del CP por LO 5/2010, la aplicación en España de la Convención de Lucha contra la Corrupción de Agentes Públicos Extranjeros en las Transacciones Comerciales Internacionales y otros instrumentos relaciona$\operatorname{dos}^{89}$. Su valoración respecto a España fue negativa en lo que se refiere al cumplimiento de las leyes españolas del cohecho internacional. En nuestro país no había tenido lugar ni un solo proceso ante los tribunales españoles, desde la vigencia del Convenio de la OCDE, sobre el delito de corrupción en las transacciones comerciales internacionales ${ }^{90}$. Consecuentemente, el informe hizo un llamamiento a España para completar la reforma de su CP mediante la consolidación o la armonización de los delitos por cohecho de funcionarios públicos extranjeros y por soborno de funcionarios europeos, delitos separados, así como para la eliminación de la excepcionalidad existente sobre las empresas públicas en el marco del CP. Pero aparte de la calificación recibida, también se destacaron los aspectos positivos de la

${ }^{87}$ N. J. DE la Mata BARRAnCo, Derecho penal europeo y legislación española: las reformas del Código Penal, actualizado a la reforma penal 2015, Valencia, Tirant lo Blanch, 2015, p. 193.

${ }^{88}$ El grupo de trabajo sobre cohecho - formado por los treinta y cuatro países miembros de la OCDE más Argentina, Brasil, Bulgaria, Colombia, Rusia y Sudáfrica- aprobó el informe de España en su tercera fase de seguimiento de la aplicación de la Convención OCDE contra el Soborno e incluye una descripción general de las medidas de ejecución reciente y las características institucionales del marco de España para la lucha contra el cohecho internacional.

89 Phase 3, Report on Implementing the OECD Anti-Bribery..., op. cit.

90 Adicionalmente, a 12 de junio de 2014, el grupo de trabajo sobre anticorrupción de la OCDE emitió algunas declaraciones del estado de situación de la corrupción en España (bttp://www.oecd.org/daf/anti-bribery/espana-debe-modificar-su-codigo-penal-y-bacer-cumplir-los-delitos-de-cohecho-internacional.htm), así como la del 8 de junio de 2013, en la que manifiesta la profunda preocupación de la OCDE por la falta de acusación de ningún delito de cohecho (ante tribunales) durante trece años, desde la firma del Convenio OCDE, dado que la reforma del Código Penal ha resultado insuficiente y debe endurecer las normas penales ( $h t t p: / / w w w . o e c d . o r g / d a f / a n t i-b r i b e r y / o e c d s e r i o u s l y c o n c e r n e d b y a b s e n c e o f f o r e i g n b r i-$ beryconvictionsinspain.btm), y las advertencias anteriores del 31 de marzo de 2006 (bttp:// www.oecd.org/corruption/spainshouldintroducefullcorporateliabilityandfinestobettercombatbriberyofforeignpublicofficialssaysoecd.htm). 
reforma de nuestro CP mediante la LO 5/2010, la responsabilidad penal de las personas jurídicas y el soborno de funcionarios extranjeros ${ }^{91}$.

Hay que aclarar que todas las demandas sobre cohecho internacional se habían archivado cuando los delegados del grupo de trabajo visitaron España en julio del año 2013, sin que en aquella fecha hubiera procedimiento alguno contra nadie y pese a que se habían identificado a dieciséis personas sospechosas en tres de esos casos. Los expedientes se referían a sobornos de empresas españolas en Costa Rica, Libia, Angola, Marruecos y Letonia por exportaciones de material militar o/y por violación del programa de la ONU. La OCDE manifestó su descontento por que no se hubieran incluido, junto a esa lista de siete investigaciones, otras alegaciones de sobornos conocidas para las que no fue competente la Fiscalía Anticorrupción española ${ }^{92}$.

Otra de las evaluaciones que recibió España provino de la Comisión Europea, que efectuó una serie de recomendaciones específicas en su informe Anticorrupción $2014{ }^{93}$ respecto a nuestro país ${ }^{94}$.

Las iniciativas patrias en materia de corrupción y de cohecho transnacional no han logrado instaurar medidas efectivas de apoyo para la persecución de estas conductas. La definición de las conductas típicas, el momento de su consumación y la imposición de penas para el particular y el funcionario que soborna todavía no ha quedado meridianamente clarificada, dando lugar a problemas interpretativos. Se hace preciso regular

${ }_{91}$ Sin embargo, no debe perderse la perspectiva positiva de que España está incluida en el grupo de catorce países con una implementación significativa de la Convenio OCDE de lucha contra la corrupción de agentes públicos extranjeros en las transacciones comerciales internacionales, junto a Bélgica, Bulgaria, Dinamarca, Francia, Alemania, Hungría, Italia, Corea, Holanda, Noruega, Suecia, Suiza y Estados Unidos.

${ }_{92}$ Fiscalia General Del Estado, Memoria del 2014, pp. 270-299, disponible en bttps:// $w w w$.fiscal.es/fiscal/PA_WebApp_SGNTJ_NFIS/descarga/MEMFIS14.pdf?idFile $=d d 3 f f 8 f c$ $d 0 c 5-472 e-84 d 2-231 b e 24 b c 4 b 2$.

93 Informe de corrupción en la Unión Europea, Bruselas, 3 de febrero de 2014 [COM(2014), 38 Anexo final 9].

94 Dentro de dicha evaluación son dignas de destacar las siguientes recomendaciones para las actuaciones que afectan al cohecho en el sector privado: a) la reforma legislativa sobre la financiación de partidos políticos, centrándose en la supervisión de los préstamos, la mejora de los controles financieros internos y mayores controles exhaustivos por el Tribunal de Cuentas, así como un régimen de sanciones reforzado; $b$ ) el desarrollo de códigos de conducta aplicables a todo el sector público; c) el refuerzo de la coherencia de las normas sobre publicidad patrimonial y los conflictos de intereses para los cargos electos y de libre designación; d) la garantía del necesario marco de aplicación de la nueva Ley de Transparencia; $e$ ) el perfeccionamiento de las prácticas en la contratación pública a través de evaluaciones independientes, y $f$ ) el incremento de la capacidad del Tribunal de Cuentas central y de organismos similares a nivel regional. 
otros elementos típicos necesarios para una persecución multidisciplinar, pues los delitos de corrupción están en constante evolución y mutación casuística. Tras las deficiencias detectadas en las distintas evaluaciones puede concluirse que no existe en España un sistema eficaz de prevención, detección y persecución de los delitos de corrupción, en concreto, de los delitos de corrupción en las transacciones comerciales internacionales. El tipo continúa siendo difuso debido a la falta de claridad de sus elementos, y no hay remisión normativa que colme las lagunas conceptuales. De igual modo, no existe la protección de testigos ni se incentiva a los denunciantes sobre asuntos de corrupción ${ }^{95}$. Tampoco se contempla como consecuencia directa del delito de cohecho trasnacional el enriquecimiento ilícito sobre el incremento patrimonial no justificado del propio funcionario público ${ }^{96}$.

\section{EL COHECHO PLURIOFENSIVO DE LOS DELITOS DEL ART. 286 TER CP}

El bien jurídico protegido en los delitos de corrupción no es unívoco, como tampoco lo es su concepto. La corrupción se encuentra en constante movimiento, aunque todas sus formas de manifestación plasman el abuso de una posición de poder y la consecución de una ventaja patrimonial a cambio de la utilización de esa soberanía o mando ${ }^{97}$. Siempre deben concurrir dos sujetos para que pueda hablarse de cualquier tipo de soborno. En el presente supuesto, la conducta de la persona física o jurídica y la del funcionario público desencadenan la lesión al bien jurídico protegido del cohecho cometido en el ámbito del tráfico económico internacional.

95 Spain: Follow-up to the phase 3 report E recommendations, marzo de 2015, disponible en http://www.oecd.org/daf/anti-bribery/Spain-Phase-3-Written-Follow-Up-Report-EN.pdf .

${ }_{96}$ No es ni mucho menos la única carencia detectada. Según las estadísticas de la Memoria Anual de la Fiscalía Anticorrupción de 2014, en el ejercicio anterior a 2013-2014 habían sido tramitados veintiséis expedientes, de los cuales a final de año quedaban catorce por resolver. Los denunciantes suelen preferir a la policía para explicar sus asuntos o los medios de comunicación. En cualquier caso, toman la iniciativa por decisión propia a sabiendas de que no van a obtener ningún tipo de protección. «Al único que se ha protegido ha sido a Hervé Falciani», señala una fuente policial, aludiendo al ingeniero de sistemas italo-francés autor de la lista Falciani en la que constaban los nombres de 130.000 evasores fiscales con dinero en la filial suiza del banco HSBC y que, desde 2009, estuvo colaborando con las autoridades de diversos países. De esos evasores, 1.500 eran españoles; los nombres de Botín y Correa estaban entre ellos, y sobre el primero sí que se ejerció una protección eficaz y necesaria; el art. 20 de la Convención de Mérida exigía la necesidad del decomiso de los efectos de la corrupción.

${ }_{97}$ C. MüLlER, Die Bestechung gemäss $\$ 4$ lit.b UWG, Bamberg, Difo Druck GmbH, 1997, p. 60. 
Los elementos culturales e históricos que definen la impunidad o no de una conducta corrupta, así como su habitualidad en determinadas sociedades, significan un importante factor para apreciar la tipicidad y, en consecuencia, valorar si se ha lesionado o no un bien jurídico concreto. Sin embargo, al margen de discusiones de carácter ético, social o incluso jurídico, no se puede transformar una sociedad corrupta en una incorrupta tan sólo recurriendo al Derecho penal y creando preceptos que pretendan abarcar todas las formas de corrupción. Ello ni es posible ni tampoco deseable, puesto que sería contrario al principio de intervención mínima que informa el Derecho penal ${ }^{98}$.

Únicamente los bienes jurídicos de mayor relevancia social merecen protección penal frente a acciones u omisiones corruptas y típicas. Es conveniente distinguir entre el contenido social de las actuaciones de corrupción y la declaración judicial o legal de corrupción, pues la ofensa al bien jurídico debe interpretarse sólo a la luz de los elementos típicos de cada conducta, tal como se acaba de apuntar. Una misma conducta puede ser constitutiva de un pequeño acto de corrupción privada y, por tanto, puede llegar a ser calificada como fraude en sede civil o mercantil, pero no será penalmente punible si no está tipificada.

El esclarecimiento del bien jurídico protegido en los delitos de corrupción de las transacciones comerciales internacionales requiere observar con carácter conexo otros bienes jurídicos dentro del ámbito del orden socioeconómico, debido a la nueva ubicación sistemática del art. 286 ter, en concreto: el bien jurídico protegido del delito de la corrupción entre particulares del art. 286 bis, ya que se encuentra en la misma sección $4 .^{a}$ relativa a la corrupción en los negocios, y el objeto protegido del delito de cohecho activo. La intervención de un agente público en los delitos analizados, el paralelismo de la conducta típica con el delito de cohecho, así como su ubicación antecedente en el título XIX del CP relativo a los delitos contra la Administración Pública, motiva la conexidad y paralelismo estructural con el delito de cohecho. Los delitos del art. 286 ter son infracciones penales pluriofensivas, pero antes de proceder a su definición precisa se debe realizar un breve inciso para delimitar los intereses colectivos que lesiona la corrupción.

${ }_{98}$ K. VoLK, Empfeblen sich Änderungen des Straf-und Strafprozessrechts, um der Gefahr von Korruption im Staat, Wirtschaft und Gesellschaft wirksam zu begegnen? Verhandlungen des einundsechzigsten deutschen Juristentages, vol. II/1, Sitzungsberichte-Referate und Beschlüsse, München, Bek'sche Verlagsbuchhandlung 1996, p. 53. 


\section{Lesión de intereses colectivos en la corrupción}

El intento de definir positivamente el bien jurídico de la corrupción, en el cual influyen en gran medida los fenómenos de la relatividad social y de la política jurídica, puede conducir a una intersección del axioma entre la vaguedad y la selectividad ${ }^{99}$. A fin de esclarecer más adelante el bien jurídico del soborno transnacional se elegirá el criterio de la selectividad, puesto que la corrupción en sí invita a debatir sobre la vaguedad de todos los conceptos que engloba y la volatilidad de su consideración en las distintas comunidades internacionales.

La cultura e historia donde se incardina la corrupción y desde la que se juzga desempeñan un papel fundamental para la definición de la lesividad de la conducta corrupta y la averiguación del bien jurídico de cuño colectivo que deberá protegerse en cada ocasión. La corrupción penal se refiere exclusivamente a conductas que el legislador ha ido seleccionando y tipificando. En cambio, la corrupción social representa conductas manifestadas en la vida real que cada individuo o grupo reprocha en función de sus propios criterios ${ }^{100}$.

Como ya se apuntó, el significado jurídico penal de la corrupción se encuentra vinculado a la criminalidad organizada y a la criminalidad de empresa ${ }^{101}$, extendiéndose ésta a muchos sectores dignos de protección y de acuerdo con los intereses en cuestión, tales como la libre competencia, el libre desenvolvimiento de los mercados, el sector público y el políti-

${ }^{99}$ R. Hefendehl, «¿Debe ocuparse el Derecho penal de riesgos futuros? Bienes jurídicos colectivos y bienes de peligro abstracto», Revista Electrónica de Ciencia Penal y Criminología, núm. 4 (2002), p. 3.

100 A. Nieto García, Corrupción en la España democrática, Barcelona, Ariel, 1997, p. 74.

${ }^{101}$ La corrupción se asocia con la criminalidad organizada y los delitos de corrupción en las transacciones comerciales internacionales están relacionados, por lo general, con la criminalidad de empresa. No se descarta la posibilidad de la intervención del crimen organizado o la comisión del delito por particulares, si bien lo habitual será que los delitos partan de una organización empresarial o de personas que actúan con un mismo fin y contribuyen a la consecución de un resultado ilícito. Vid. OCDE, Foreign bribery report: An analysis of the crime of bribery of foreign public officials, diciembre de 2014, disponible en bttp:// dx.doi.org/10.1787/9789264226616-en. A nivel estadístico, la corrupción con agentes públicos extranjeros tiene lugar, las más de las veces, a través de empresas y PyMES con más de 250 trabajadores, y cuentan adicionalmente con una proyección internacional. Así se constató en el último informe de la OCDE de 2014 sobre los índices de corrupción relacionados con los delitos proscritos en el Convenio de la OCDE. También se puso de manifiesto que en el 12 por 100 de los casos, las personas que corrompían a los agentes públicos extranjeros ostentaban el cargo de presidente o director general de grandes compañías multinacionales. 
co, así como el secreto de empresa. No obstante, y a pesar de dichas áreas de interés, la corrupción en el funcionamiento de la Administración Pública es la que seguramente continúa mereciendo mayor atención, bien debido a su carácter público, bien en el ámbito comparado como en nuestro CP español ${ }^{102}$.

En el ámbito de la progresiva globalización, las condiciones esenciales que rigen la convivencia social adquieren una dimensión supranacional no ya porque los distintos Estados compartan iguales valores (lo que resulta sencillo cuando se trata de las prerrogativas fundamentales: vida, salud, dignidad), sino porque esos valores sólo adquieren sentido en la medida en que se manifiestan en el marco universal, porque son valores cuya existencia sirve de fundamento a esa comunidad global ${ }^{103}$.

$\mathrm{El}$ incremento del riesgo de comisión de conductas corruptas se extiende en el contexto de la globalización de la economía, de la liberalización del mercado y del avance de las tecnologías de la información, con la consiguiente comercialización universal de nuevos productos. Este riesgo no sólo dota de mayor significado a la posición de garante del funcionario público respecto de los bienes que administra, sino también a los principios en los que debe desenvolverse el tráfico y comercio internacionales, así como a las inversiones que trascienden las fronteras nacionales. Los bienes jurídicos relativos a la protección de los intereses generales, según el correcto funcionamiento de la Administración Pública y en paralelo a la competencia leal y la libre circulación de bienes y servicios en el tráfico internacional, pueden verse lesionados por cualquier persona privada, ya sea física o jurídica, que soborne o acepte un soborno de un funcionario público extranjero. Sin embargo, los bienes jurídicos protegidos en tales delitos de corrupción resultan en cierta manera genéricos e indeterminados, y por esa razón debe prestarse atención a la conducta concreta ejecutada y a los medios comisivos utilizados ${ }^{104}$.

102 N. J. De la Mata BarRanco, «El bien jurídico protegido en el delito de cohecho», Revista de Derecho Penal y Criminología (RDPC), 2. época, núm. 17 (2006), pp. 84-85.

103 E. Fabián Caparrós, La corrupción de agente público..., op. cit., p. 180.

104 Piénsese también en la complejidad si además se comete por una persona jurídica. Vid. F. Rodríguez Almirón, «La responsabilidad penal de las personas jurídicas a raíz de la jurisprudencia reciente del Tribunal Supremo», Revista Aranzadi Doctrinal, num. 6 (2017), pp. 107-129. 


\section{Intereses jurídicos que componen el bien jurídico protegido de los delitos del art. 286 ter}

El bien jurídico de los delitos del art. 286 ter resulta complejo de definir debido a la agrupación de elementos típicos que contiene, a los compromisos internacionales adquiridos de los que proviene y a las pautas interpretativas que marcaron su antigua y su nueva ubicación dentro del título del CP relativo a los delitos socioeconómicos.

La naturaleza pluriofensiva de estos delitos se desprende de la lesión a la competencia leal y a la imparcialidad de los funcionarios públicos extranjeros y de organizaciones internacionales. Ello se refleja claramente en el siguiente ejemplo: las empresas que corrompen a un funcionario público para obtener una ventaja competitiva perjudicarán a los competidores y generarán una economía poco eficiente instigada por la desviación del correcto ejercicio de la función pública a favor de intereses particulares ${ }^{105}$.

La lesión de la competencia leal del mercado se desprende sólo de aquella corrupción relevante y con capacidad lesiva para desestabilizarla. El énfasis en estas conductas corruptas debe ponerse en el análisis del contenido del injusto penal, a través del que parece pretenderse controlar las riendas de un Derecho penal en expansión ${ }^{106}$.

\section{A. Similitudes con el bien jurídico protegido en la corrupción entre particulares}

La protección penal frente a las conductas de corrupción privada se centra en la garantía de una competencia justa y honesta, franqueando la represión de los actos encaminados a corromper a los administradores de entidades privadas de forma parecida a lo que se hace a través del delito de cohecho. Dichos comportamientos exceden la esfera del patrimonio privado y rompen las reglas de buen funcionamiento del mercado y de la competencia leal que protege la Ley de Defensa de la Com-

105 Memento Práctico Penal Económico y de la Empresa, Madrid, Francis Lefebvre, 20162017, pp. 670-671.

106 B. FeIjoo SÁncheZ, «El delito de corrupción de agentes públicos en actividades económicas internacionales del art. 286 ter CP como delito contra la competencia a través de la corrupción», Diario La Ley, núm. 8987 (2017). 
petencia ${ }^{107}$. La importancia del problema es grande si se repara en la repercusión que pueden tener las decisiones empresariales no sólo para sus protagonistas inmediatos, sino para otras muchas personas. Evidentemente, las empresas públicas o las empresas privadas que presten servicios públicos serán sometidas a la disciplina penal del cohecho, omitiéndose por voluntad legal la condición formal de la intervención de funcionario público ${ }^{108}$.

La competencia constituye uno de los principios rectores de la economía de mercado, y la libertad de empresa afecta, por tanto, a las libertades individuales si no se desarrolla bajo los principios de una competencia libre y honesta. La competencia libre debe ser aquella que existe en el mercado cuando los oferentes producen bienes o servicios y los consumidores eligen libremente sus compras partiendo de una información fidedigna y transparente sobre las características de precio y calidad de los productos ${ }^{109}$.

La justificación a la incriminación de las conductas corruptas en el ámbito privado y semipúblico puede buscarse en el respeto a la competencia leal y equitativa. La corrupción distorsiona las reglas de competencia en la compraventa de bienes y servicios en el mercado e impide el desarrollo económico. Ello ocurre tanto en el sector privado como también en el sector público. En definitiva, se trata de un mercado único diferenciado internamente en público y privado con base en el tipo de gestión. La lesión puede alcanzar ambos sectores, pero entonces las consecuencias garantistas y económicas pueden ser diferentes y exceder el ámbito privado.

El bien jurídico protegido se concibe, en parte, como una vertiente de la competencia leal del mercado; ello posibilita excluir de las conductas típicas aquellas que no se vean afectadas por las reglas de competencia, debido a que no existe una competencia efectiva en un determinado contexto o porque estén amparadas por los usos sociales ${ }^{110}$, lo mismo que sucede con determinadas dádivas y el cohecho impropio. La protección de la libertad de competencia implica preservar la función económi-

107 Ley 15/2007, de 3 de julio, de Defensa de la Competencia.

108 Preámbulo XIX de la LO 5/2010, de 22 de junio, de reforma del CP. La reforma trae causa de la transposición de la Decisión Marco 2003/568/JAI, relativa a la lucha contra la corrupción en el sector privado.

109 H. Demsetz, La competencia: aspectos económicos, jurídicos y políticos, Madrid, Alianza Editorial, 1986, p. 25.

110 P. Otero GonzÁlez, «Corrupción entre particulares (delito de)», Eunomía. Revista en Cultura de la Legalidad, núm. 3 (2012), p. 177. 
ca de calidad-precio y su función político-social, la posibilidad de acceso a otros competidores y la posibilidad de elección del consumidor. El hecho de que el tipo penal se halle ubicado dentro del capítulo XI sirve además de criterio interpretativo ${ }^{111}$. La tipificación de este delito pretende salvaguardar la competencia empresarial o profesional en la contratación de bienes y servicios, con la consiguiente afectación al normal funcionamiento de mercado ${ }^{112}$.

No obstante, los modelos de incriminación en Derecho comparado en cuanto a la corrupción en los negocios resultan variopintos, si bien todos reconocen la lesión a la libre y leal competencia del mercado. En Francia se opta por incriminar también la infracción del deber de fidelidad del trabajador respecto de la administración desleal que puede llegar a cometer con la empresa para influir así en el mercado, mientras que en Austria se vincula la corrupción privada a la deslealtad patrimonial entre mandatario y mandante. El modelo omnicomprensivo de Suecia es el que más llama la atención, ya que regula un delito común aplicable tanto a sujetos públicos como privados, sin hacer distinción entre corrupción privada y corrupción pública ${ }^{113}$.

La unificación de la tipificación de las conductas corruptas tanto para el ámbito privado como para el público tiene su sentido lógico, aunque aquí no poseería encaje sistemático en nuestro $\mathrm{CP}$ ni en nuestra tradición histórica y legislativa; el ordenamiento jurídico español desvincula y regula de forma separada, en todos los aspectos, el sector público y el sector privado.

111 P. OTERO GonZÁLEZ, «Los nuevos delitos de corrupción en los negocios tras la reforma penal por LO 1/2015 (análisis de cuestiones concretas de los arts. 286 bis y 286 ter CP)», en M. Villoria Mendieta, J. M. Gimeno Feliú y J. Tejedor Bielsa (dirs.), La corrupción en España. Ámbitos, causas y remedios jurídicos, Barcelona, Atelier, 2016, pp. 451 y ss.

112 J. NAVARRO MASSIP, «El delito de corrupción entre particulares», Revista Aranzadi Doctrinal, núm. 8 (2011), pp. 43-50.

113 P. Otero GonzÁlez, «Corrupción entre particulares...», op. cit. p. 178, y A. GILI PASCUAL, «Bases para la delimitación del ámbito típico en el delito de corrupción privada (contribución al análisis del art. 286 bis del Código Penal según el Proyecto de reforma de 2007)», Revista de Derecho Penal y Criminología, núm. 19 (2007), pp. 245-288, en relación con el delito de corrupción entre particulares en el Código Penal francés y su desvinculación del ámbito iuslaboralista, pasando al ámbito comercial, en cuanto al incumplimiento del deber de fidelidad del trabajador con la empresa. Vid. también J. L. DE LA CuESTA ARZAMENDI, «La criminalización de la corrupción en el sector privado: ¿asignatura pendiente del Derecho penal español?», en J. L. Díez RIPOLLÉs (coord.), La ciencia del Derecho penal ante el nuevo siglo. Libro bomenaje al profesor D. José Cerezo Mir, Madrid, Tecnos, 2002, pp. 257-290, en lo que atañe a la regulación del $\mathrm{CP}$ austriaco del delito de corrupción entre particulares y su visión respecto de la lesión al bien objeto de tutela. 
Además de lo anterior, se suma el infortunio de que la doctrina penal, en su mayor parte, consideró que el legislador no había acertado en la tipificación penal del delito de corrupción entre particulares, pues no había razón suficiente para penar la corrupción privada; parecía que respondía más bien a una tendencia legislativa hacia un Derecho penal simbólico en lugar de acercarse a un Derecho penal basado en principios de lesividad y exclusiva protección de bienes jurídicos. El objeto de protección del delito de corrupción entre particulares es la competencia en el mercando, pero, en realidad, se incriminan conductas escasamente lesivas a dicho interés jurídico, so pretexto de la falta de ética que existe en los negocios y de que dichas conductas se evidencian. Se sanciona el comportamiento venal de administradores y empleados en el ámbito de sus responsabilidades en los negocios, pero se sanciona por la mera concurrencia de la venalidad y no por la efectiva lesividad de esas conductas venales hacia la libre competencia ${ }^{114}$. Partiendo de esta premisa, que considera innecesaria la tipificación de la corrupción entre particulares, se puede afirmar que el delito de corrupción entre particulares y el soborno transnacional son delitos diferentes, que no necesitan el uno del otro en su existencia y que tan sólo comparten un aspecto del bien jurídico protegido y algunos elementos típicos del clásico cohecho. A mayor abundamiento, la presencia de un funcionario público, junto con la finalidad específica de obtener un contrato o negocio en marco económico internacional y la gravedad de acometer una lesión al sector público, posicionan los delitos del art. 286 ter en un lugar distinto de los del art. 286 bis para argumentar su existencia legislativa y su enjuiciamiento de forma separada.

Los delitos de corrupción en los negocios comparten un denominador común que es la lesión a la leal competencia del mercado y la conducta de un soborno, pero son delitos absolutamente diferentes e independientes entre sí. La presencia de un funcionario público, junto con la finalidad específica de obtener un contrato o negocio en marco económico internacional y la gravedad de acometer una lesión al sector público, constituyen elementos típicos diferenciadores que concurren sólo en el cohecho transnacional. Los delitos de corrupción en las transacciones comerciales internacionales comportan la alteración de una afectación del mercado internacional y, por extrapolación, también perturba el mercado español.

114 A. Ventura Püschel, «Corrupción entre particulares», en F. J. Álvarez García y J. L. GonzÁlez Cussac (dirs.), Comentarios a la reforma penal de 2010, Valencia, Tirant lo Blanch, 2010, pp. 266 y 321. 
Las conductas del delito del art. 286 ter lesionan de forma más concisa - dentro de la competencia leal del mercado- el libre desenvolvimiento de la competencia en el tráfico comercial internacional, incidiendo en el mercado público y privado. Por tanto, puede concluirse que la finalidad perseguida en los delitos de corrupción en las transacciones comerciales internacionales tiende a proteger la libre competencia del mercado y el ejercicio de funciones públicas a nivel nacional o internacional ${ }^{115}$. Esta doble naturaleza establece una estrecha relación entre esos bienes de cuño colectivo.

\section{B. Paralelismo con el bien jurídico protegido en el delito de cobecho}

El delito de corrupción en las transacciones comerciales internacionales está compuesto, entre otros muchos elementos típicos, por una refundición del tipo de cohecho con algunos matices del tipo de corrupción entre particulares, pues puede lesionar la competencia leal del mercado, pero también el correcto funcionamiento de la Administración Pública, teniendo en cuenta la bilateralidad de las conductas y la intervención de un agente público.

El paralelismo de estos delitos con el delito de cohecho fue una de las razones por las cuales se situó el injusto, hasta la reforma de la LO 1/2015, en el título XIX relativo a los delitos contra la Administración Pública. El bien jurídico de los delitos de corrupción en las transacciones comerciales y el de los delitos de cohecho coincide en el ataque al correcto desempeño de la función pública ${ }^{116}$. La única diferencia estriba en que el cohecho internacional, según se interpretó con anterioridad, además de proteger el normal funcionamiento de la Administración Pública, también protegía el de las organizaciones internacionales y la transparencia frente a la corrupción de autoridades o funcionarios públicos extranjeros o de organizaciones internacionales. Se consideró que tutelaba la imparcialidad en el cumplimiento de las obligaciones de tales funcionarios ${ }^{117}$. La vinculación de los delitos de corrupción en las transacciones comerciales internacionales con el correcto funcionamiento de la Administración Pública españo-

115 J. Díaz Maroto y Villarejo, «El delito de corrupción en las transacciones económicas internacionales (art. 445 del Código Penal) (1)», La Ley, año XXVIII, núm. 6.740 (2007), p. 203.

116 M. Cugat Mauri, en J. Córdoba Roda y M. García Arán, Comentarios al Código Penal. Parte especial, t. II, Madrid-Barcelona, Marcial Pons, 2004, p. 2116.

117 A. Serrano Gómez, Derecho penal. Parte especial, Madrid, Dykinson, 2001, pp. 780-781. 
la y extranjera es innegable. La ubicación sistemática anterior que poseyó este injusto y la similitud de la nueva redacción del tipo del art. 286 ter respecto de la anterior del art. 445 justifican que deba acudirse a los delitos de cohecho para realizar un análisis comparativo no sólo en relación con los elementos típicos estructurales, sino también en lo que al bien jurídico protegido atañe.

Los delitos del nuevo art. 286 ter aún revisten un claro paralelismo estructural con el tradicional delito de cohecho. Los elementos del tipo objetivo y del tipo subjetivo de ambos delitos son cuasi idénticos y, por tanto, resultará decisivo cómo se perfile el bien jurídico protegido en los delitos de cohecho para el análisis de los delitos de corrupción en las transacciones comerciales internacionales, pues en ambos interviene un funcionario público.

Es soborno aquel acuerdo o trato adoptado entre el particular y el funcionario público donde se persigue como finalidad la obtención, posible o resultante, de un acto o resolución determinado o determinable. La verificación del acto deberá ser contraria a Derecho y al principio de legalidad, aunque caben, asimismo, supuestos en que el acto puede ser reglado e ilícito. Estos supuestos de actos corruptos, que son reglados dentro de las competencias del funcionario público, constituyen un fraude de ley ${ }^{118}$, dado su contenido intrínseco, ya que contrarían el principio de prohibición de la arbitrariedad en el ejercicio de la función pública y de ahí la ineludible remisión al art. 103 CE.

El objeto de protección jurídica en el delito de cohecho no siempre ha estado definido por la doctrina de forma igualitaria, pudiendo contemplarse desde la perspectiva de los sujetos que toman la iniciativa corrupta, ya sea el particular o funcionario público, o desde la perspectiva de la naturaleza del acto que realice el funcionario como consecuencia del soborno. Existen varios tipos y subtipos del delito de cohecho. Estos planteamientos para definir el bien jurídico desde un punto de vista subjetivo o sustantivo no impiden, sin embargo, que el desvalor de la conducta sea el mismo, con independencia de que el objeto del acuerdo sea típico o no, ilegal, reglado o incluso cuando no exista acuerdo corrupto expreso. La contraprestación del funcionario puede ser antecedente, coetánea o subsecuente a la dádiva entregada, prometida o recibida. Pero cuando se trata de establecer

118 Art. 6.4 CC: «Los actos realizados al amparo de una norma que persigan un resultado prohibido por el ordenamiento jurídico, o contrario a él, se considerarán ejecutados en fraude de ley y no impedirán la debida aplicación de la norma que se hubiere tratado de eludir». 
un reproche penal unívoco en la diferenciación de conductas se complica la cuestión. Para definir la naturaleza del comportamiento deberá atenderse al enriquecimiento personal e indebido obtenido por los sujetos. Tal perspectiva sustantiva para definir el bien jurídico protegido ha sido criticada en parte. El legislador no considera necesario intervenir penalmente ante el acto ilícito, que en ocasiones podrá ser no penal o lícito, al cual se compromete a ejecutar el funcionario, cuando viene motivado por una razón diferente a la del lucro económico ${ }^{11}$. Desde la perspectiva del enriquecimiento ilícito y dentro del catálogo de las infracciones penales contra la Administración Pública, los delitos de cohecho adquieren mayor relevancia social y gravedad que otros delitos de corrupción, porque la interactuación de dos sujetos distintos, funcionario y particular, es imprescindible para que pueda hablarse de injusto.

Coinciden los autores en destacar que los delitos contra la Administración Pública son delitos constitucionales y políticos que se materializan a través de un ejercicio abusivo del cargo, esto es, abusando de una situación jurídica idónea ${ }^{120}$. La relación de servicio que mantiene el funcionario con la Administración debe desenvolverse en interés exclusivo de la comunidad de ciudadanos, ya que se trata de facultades preconcebidas al funcionario que deben ser utilizadas de manera exclusiva para perseguir fines institucionales del Estado. Tanto es así que para dilucidar la forma de lesión al bien jurídico, según el tipo de cohecho, debe acudirse a la definición de la antijuridicidad y culpabilidad de cada tipo, sin perjuicio de que algunos juicios de antijuridicidad ${ }^{121}$ puedan desembocar en una reflexión entre moral y Derecho respecto de los deberes de naturaleza ética. Ello puede derivar en cuestiones que no corresponden al Derecho penal especial, si bien es preciso destacar que la moral, la ética y los principios de

119 N. J. DE la MATA BARRANCO, «El bien jurídico protegido...», op. cit.: «Con todo, por razones más de carácter político-criminal que dogmático, y no dejando de reconocerse la vinculación en varias de las figuras de cohecho con una actuación del funcionario paralela, lo cierto es que en la actualidad no hay ordenamiento que no contemple el delito de cohecho de forma autónoma, aunque su configuración típica se haga dependiente —objetiva o subjetivamente- de una actuación posterior —o anterior - del funcionario, de carácter preferentemente ilícito. Y, sin embargo, dicha autonomía sólo se justificará si podemos definir un concreto objeto de tutela que difiera del tutelado en otros preceptos. De lo contrario estaríamos simplemente ante tipificaciones falsamente autónomas por representar meros adelantamientos de la intervención penal en relación con otros preceptos del Código» (p. 89).

120 E. Bacigalupo Zapater, «Sobre la reforma de los delitos de funcionarios», Documentación Jurídica, vol. II, núm. 37/40 (1983), pp. 1093-1095.

${ }^{121}$ Éste sería el caso del cohecho impropio o de considerar típica o atípica la entrega de una dádiva, según las circunstancias de cada caso. 
prevención general pueden contribuir positivamente a completar la concepción del bien jurídico protegido en esta clase de delitos ${ }^{122}$. Un delito de cohecho impropio deberá analizarse desde la óptica de la ética y la moral, y desde los principios de la prevención general, a fin de que pueda catalogarse como conducta impune o punible y lesiva para el bien jurídico protegido. Por consiguiente, y con objeto de lograr una definición adecuada del bien jurídico, siempre se debería atender a la finalidad que reviste la conducta delictiva del delito de cohecho, y ésta en cualquier caso será fraudulenta y corrupta sin necesidad de que se cumplan ciertos requisitos respecto a la realización del tipo, pues la conducta puede resultar ilícita y aparentemente atípica con el fin de lograr la ocultación de un resultado típico de corrupción, como sucede en el cohecho impropio.

En el estudio de la lesión al bien jurídico de cualquier delito de soborno también se plantea la disyuntiva sobre la gravedad de la lesión al bien jurídico protegido en torno a la condición del sujeto activo. La cualidad del sujeto activo constituye una condición fundamental, bien sea en este caso el funcionario público o el particular el que toma la iniciativa y requiere al otro para delinquir. Sin embargo, esta postura ha sido muy discutida en relación con los tradicionales delitos de cohecho. Supone un riesgo que la clasificación del bien jurídico dependa de la cualidad del funcionario, porque entonces la dialéctica podría derivar en una concepción subjetiva del injusto, desligada del planteamiento objetivo que requieren otros delitos conexos ${ }^{123}$. Un funcionario público que ofrece, propone o solicita la dádiva de un particular para cometer delito de cohecho quebranta todas las garantías derivadas del principio de legalidad. El servicio que mantiene el funcionario con la Administración debe desenvolverse en interés exclusivo de la comunidad de ciudadanos. Las facultades conferidas por el Estado al funcionario han de ser utilizadas de forma exclusiva para perseguir los fines institucionales del Estado. Por el contrario, un funcionario público que acepta la dádiva ofrecida o entregada por un particular está violando su deber de integridad y su deber de lealtad, además de destruir la protección de confianza que el Estado depositó en él. El cohecho pasivo, el cometido por funcionario, vulnera igualmente el deber de integridad y el deber de lealtad del funcionario público y transgrede la protección de la confianza que el Estado deposita en un funcionario. El cohecho

122 I. Valeije Álvarez, «Consideraciones sobre el bien jurídico protegido en el delito de cohecho», Estudios Penales y Criminológicos, núm. 18 (1994-1995), pp. 295-369.

123 M. Cobo del Rosal, Derecho penal español..., op. cit., p. 443. 
activo, por su parte, se diferencia del pasivo por razón de que el particular y la Administración no están ligados por ningún vínculo contractual, aunque se altera el normal funcionamiento de las funciones públicas, afecta a la dignidad del Estado, al prestigio social y a la obligación de respeto; en otras palabras, el particular que delinque por medio del cohecho al aceptar o solicitar la exigencia de recompensa ilícita del funcionario público provoca una alteración del normal funcionamiento de la Administración Pública. El particular no posee ningún vínculo contractual con la Administración, pero está incitando al funcionario a quebrantar su deber para con el cargo ${ }^{124}$. La ofensa al bien jurídico en el cohecho activo, cuya iniciativa corrupta proviene del particular, no debe referirse a un estado propio del funcionario, sino a la desviación del servicio público o a la corrupción de la función en el supuesto concreto ${ }^{125}$. Esta modalidad de cohecho constituye una infracción penal grave de un deber, del fiel desempeño del cargo $^{126}$, de lealtad ${ }^{127}$ y de probidad económica ${ }^{128}$.

En relación con el deber funcionarial, el principio de imparcialidad en la función pública se entiende como ausencia de interferencias en la adopción de decisiones públicas, que han de estar guiadas únicamente por los fines que legalmente justifiquen su desempeño ${ }^{129}$. Dicho principio de imparcialidad, aplicado al análisis del delito de cohecho, tiene que presidir toda la actividad de los funcionarios públicos y vincularse no sólo a los poderes públicos, actividad administrativa, judicial y legislativa, sino también a los particulares, y debe referirse a que el objeto tutelado en el delito de cohecho es el deber de los poderes públicos de obrar con una fundamental neutralidad y objetividad en la prestación de servicios públicos ${ }^{130}$. El soborno cometido por funcionario público, ya sea de manera pasiva o

${ }^{124}$ Debe traerse a colación la teoría de los Pflichtdelikte, entendida como la infracción

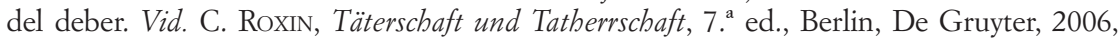
pp. 352-398.

125 E. Casas Barquero, «Algunos aspectos de los delitos del funcionario público y del particular relativos a dádivas, presentes, ofrecimientos o promesas», en Estudios penales. Libro homenaje al profesor D. Antón Oneca, Salamanca, Universidad de Salamanca, 1982, p. 659.

126 J. Catalán Sender, Delitos cometidos por autoridades y funcionarios públicos en el nuevo Código Penal (doctrina y jurisprudencia), Barcelona, Bayer Hnos., 1999, p. 193.

127 C. Granados Pérez, «El instrumento en el delito de cohecho», Cuadernos de Derecho Judicial, núm. 4 (1994), pp. 131 y 143.

128 C. Mir Puig, Los delitos contra la Administración Pública en el nuevo Código Penal, Barcelona, Bosch, 2000, p. 226.

129 F. Morales Prats y M. ${ }^{a}$ J. Rodríguez Puerta, «Título XIX. Delitos contra la Administración Pública», en Quintero Olivares (dir.), Comentarios a la parte especial del Código Penal, 5. a ed., Elcano, Aranzadi, 2005, pp. 1605 y 1860-1862.

${ }^{130}$ I. Valeije Alvarez, «Consideraciones sobre el bien jurídico...», op. cit., p. 356. 
activa, puede presentarse como un delito de lesión o de peligro ${ }^{131}$, según la conducta, porque a partir del momento en que recibe o acepta promesa de entrega de la dádiva se coloca en una posición parcial respecto al resto de los ciudadanos. Por el contrario, el cohecho cometido por particular responde no ya a la lesión, sino a la puesta en peligro del bien jurídico, dado que dicho sujeto no lleva la carga de resolver con imparcialidad y respetando la igualdad de todos los ciudadanos ante la ley, sino que únicamente posee la obligación de utilizar los cauces lícitos para la obtención de su pretensión dirigida a la Administración, sin interferir ilícitamente en la toma de decisiones, cuya adopción y tramitación no le compete.

Desde una perspectiva más amplia, el bien jurídico a proteger en el delito de cohecho se corresponde con el correcto funcionamiento de la Administración ${ }^{132}$. Hay que añadir, sin embargo, que ello comprende la no conculcación del principio de parcialidad, bien internamente por el funcionario, bien externamente por el particular ${ }^{133}$, prestando además especial atención a la proscripción de la venalidad en el desempeño de las funciones públicas, interés que se concreta en la obtención de un lucro ilícito ${ }^{134}$. Los deberes de los funcionarios y la responsabilidad institucional tienen que contemplarse, en todo caso, como los presupuestos que protegen y constituyen la antesala del verdadero bien jurídico: el interés general.

La evolución doctrinal y jurisprudencial respecto al bien jurídico tratado ha ido deslizándose desde la consideración de que está compuesto por el deber de probidad en el ejercicio del cargo funcionarial, hasta la estimación de que consiste en el correcto funcionamiento de la Administración conforme a las bases constitucionales ${ }^{135}$. No obstante, la jurisprudencia más actual matiza que debe ser la probidad del funcionario público la que permita a la Administración asegurar una prestación adecuada, objetiva y no discriminatoria de los servicios públicos ${ }^{136}$.

${ }^{131}$ F. Morales Prats y M. J. Rodríguez Puerta, «Título XIX. Delitos contra la Administración...», op. cit., p. 1610.

132 I. Olaizola Nogales, El delito de cohecho, Valencia, Tirant lo Blanch, 1999, p. 112.

133 F. Muñoz Conde, Derecho penal. Parte especial, 13. " ed., Valencia, Tirant lo Blanch, 2001, pp. 957-965.

${ }_{134}$ E. OCTAVIO DE Toledo, «Derecho penal, poderes públicos y negocios (con especial referencia al cohecho)», en AAVV, El nuevo Código Penal: presupuestos y fundamentos. Libro homenaje al profesor Torío López, Granada, Comares, 1999, p. 112.

135 C. Blanco Lozano, Tratado de Derecho penal español, t. II, El sistema de la Parte Especial, vol. 2, Delitos contra bienes jurídicos colectivos, Barcelona, Bosch, 2005, p. 358.

136 STS núm. 2025/2001, de 29 de octubre, recurso núm. 4302/1999 (ROJ 8381/2001), y STS núm. 77/2007, de 7 de febrero, recurso núm. 586/2006 (ROJ 2007/1921): «En efecto, el delito de cohecho protege en efecto ante todo el prestigio y eficacia de la Adminis- 
Octavio de Toledo acertó al afirmar que la Administración despliega su existencia en interés de la comunidad de ciudadanos a los que sirve, pero a los que no representa. Elevar la protección penal de los deberes funcionariales comportaría una visión del funcionario como mero ejecutor de órdenes recibidas, independientemente de cuál fuera el contenido lícito o ilícito de las instrucciones impartidas ${ }^{137}$. Por tanto, la teoría de la relación Administración-funcionario debe concebirse como aquella cuyo planteamiento rechaza la identificación del bien jurídico tutelado con el incumplimiento de un deber o cargo, si bien parte de la aceptación de la infracción como deber, pero entendiéndola como objeto del derecho disciplinario ${ }^{138}$. Tesis distinta, aunque posiblemente también complementaria, resulta ser el reconocimiento de la esencialidad de la relación establecida entre ciudadano y funcionario. En esta línea hay que notar otras aportaciones ${ }^{139}$, las de aquellos a los que la búsqueda y posterior determinación del bien

tración Pública garantizando la probidad e imparcialidad de sus funcionarios y asimismo la eficacia del servicio público encomendado a éstos [STS de 27 de octubre de 2006 (RJ $2006,6737)]$. Se trata, pues, de un delito con el que se trata de asegurar no sólo la rectitud y eficacia de la función pública, sino también de garantizar la incolumidad del prestigio de esta función y de los funcionarios que la desempeñan, a quienes hay que mantener a salvo de cualquier injusta sospecha de actuación venal». Vid. también STS 323/2013, de 23 abril, recurso núm. 424/2012 (ROJ 2013\6698) (caso Gürtel): «Así, en general, los delitos de cohecho son infracciones contra la integridad de la gestión administrativa al dejarse llevar el funcionario por móviles ajenos a su misión pública como lo es el lucro ilícito. Con respecto también al bien jurídico protegido en el delito de cohecho la STS de 31 de julio de 2006 (RJ 2006, 8872) afirmó que tanto en el activo como en el pasivo el bien jurídico protegido es el mismo, la recta imparcialidad en el ejercicio de la función pública y el consiguiente prestigio de esa función, pero con dos perspectivas. En el pasivo, el quebrantamiento del deber de probidad que pesa sobre el funcionario y de la confianza en él depositada; en el activo, el respeto que se debe a la función pública por quien no la está ejerciendo en el asunto de que se trate. Se trata de un interés comunitario, que no puede, por regla general, ser encarnado por ninguna persona en particular, y pertenece a la comunidad en general y por ello — como precisa la STS 5 de abril de 2002 (RJ 2002, 4267)—, la única forma de personarse en unas actuaciones penales en concepto de parte es a través del ejercicio de la acción popular».

137 E. Octavio de Toledo, La prevaricación del funcionario público, Madrid, CivitasInstituto de Criminología de la Universidad Complutense de Madrid, 1980, p. 243, y en idéntico sentido T. Vives ANTÓN, «La responsabilidad de los jueces en el Proyecto de la Ley Orgánica del Poder Judicial», Estudios Penales y Criminológicos, núm. 9 (1984-1985), p. 277, y también J. L. GonZÁlez Cussac, El delito de prevaricación de funcionario público, Valencia, Tirant lo Blanch, 1994, p. 19.

138 I. Valeije Alvarez, El tratamiento penal de la corrupción..., op. cit., pp. 336-342.

139 T. Vives AnTón, «La responsabilidad de los jueces...», op. cit., pp. 274 y ss., y también, en el mismo sentido, íD., «Delitos contra la Administración Pública», en E. ORTS Berenguer et al., Derecho penal, Parte especial, 3. a ed., Valencia, Tirant lo Blanch, 2004, pp. 632 y ss. 
jurídico protegido en los delitos de funcionarios debe construirse sobre la obligación existente para los poderes públicos de ofrecer un servicio a la comunidad, con arreglo a los principios y criterios marcados por la Constitución y el resto del ordenamiento jurídico.

El ataque al bien jurídico protegido del delito de cohecho se produce anteriormente al correcto funcionamiento de la Administración Pública y posteriormente al quebranto de los deberes funcionariales, siempre en ese orden, pero no debiendo presumirse lo uno sin lo otro. El ordenamiento jurídico debe tutelar la obligación por parte de la Administración de actuar atendiendo a la satisfacción general de todos los intereses de los ciudadanos, fomentando que se promueva y respete la imparcialidad de la función pública, esto es, de manera contraria a la arbitrariedad.

Con carácter genérico y de categorización, el bien jurídico protegido de los delitos contra la Administración Pública lo constituye, tal como apunta Mir Puig ${ }^{140}$, el correcto funcionamiento de la Administración Pública, bien sea en su vertiente objetiva de la función pública o del servicio público en su aspecto externo, la relación Administración-ciudadano, o bien sea en el aspecto interno, la organización o relación Administración-funcionario. La pureza del ejercicio público tampoco puede considerarse un bien jurídico en sí, porque se identifica con el ideal al que aspira un Estado de Derecho ${ }^{141}$, es decir, la corrección del ejercicio de la función pública de conformidad a la ley y al Derecho ${ }^{142}$.

En conclusión a lo expuesto, una visión ecléctica de los distintos enfoques para el análisis del bien jurídico de cohecho será la que más valor aporte para la definición de delitos de corrupción en las transacciones comerciales internacionales. Frente a la cada vez más temida patrimonialización de la función pública por parte de los sujetos que la integran, junto con la manipulación del Estado para satisfacer los intereses particulares de los funcionarios, debe protegerse el desempeño de la función pública de forma regular, legal y lícita con la finalidad de preservar el correcto funcionamiento de la Administración Pública y que ésta sirva a los intereses generales, respetando el principio de igualdad entre todos los ciudadanos. Este conjunto homogéneo de bienes jurídicos podrán conculcarse

${ }^{140}$ C. Mir Puig, Los delitos contra la Administración..., op. cit., p. 19.

${ }^{141}$ La definición de España como un Estado de Derecho viene plasmada en la Constitución, art. 1.1: «España se constituye en un Estado social y democrático de Derecho, que propugna como valores superiores de su ordenamiento jurídico la libertad, la justicia, la igualdad y el pluralismo político».

${ }^{142}$ H. WAGNER, Amtsverbrechen, Berlin, Dunker\&Humblot, 1975, p. 270. 
tanto en el cohecho activo como en el pasivo y tanto en el cohecho propio como en el impropio. A la luz de este enfoque en la delimitación del bien jurídico de los delitos de cohecho se analizan los intereses que conforman el bien jurídico protegido en el soborno transnacional. Las conductas del art. 286 ter, además de atacar en primera línea el correcto funcionamiento del mercado económico y comercial internacional, podrán vulnerar en segundo plano los intereses y principios anteriormente aludidos. Y la presencia de una autoridad o funcionario público, nacional, de la UE o extranjero en el tipo ocasiona que la lesión se extienda sobre el sector privado y el público.

\section{Concreción del bien jurídico protegido en los delitos de corrupción de las transacciones comerciales internacionales}

El bien jurídico protegido de estos delitos de corrupción del art. 286 ter significa el correcto funcionamiento del tráfico comercial internacional dentro del orden socioeconómico establecido. De forma colateral y a tenor de si el funcionario público sirve al Estado español o a otro extranjero, se vulnerará también el correcto funcionamiento de la Administración Pública española o el prestigio e imagen del Estado español en las relaciones comerciales internacionales frente a la Administración Pública extranjera.

El correcto funcionamiento de la Administración Pública española únicamente se verá conculcado cuando el delito lo cometa un particular con una autoridad o funcionario público español, según establece el art. 286 ter por remisión al art. $24 \mathrm{CP}$. El particular que corrompe al funcionario público español o que atiende la solicitud corrupta de dicho funcionario vulnera los principios de probidad de la función pública y el principio de igualdad de los ciudadanos frente a la Administración que sirve a los intereses generales.

En caso de que para la comisión del delito medie un funcionario público extranjero o de la UE, según determina el art. 286 ter por remisión al art. $427 \mathrm{CP}$, se pondrá en entredicho el prestigio internacional en las relaciones diplomáticas e internacionales que mantiene el Estado español a través de su Administración Pública con el Estado extranjero al que pertenezca el funcionario público extranjero en cuestión.

Al calificar el delito de corrupción en las transacciones comerciales internacionales como un delito común de carácter unisubjetivo, surge inevitablemente la pregunta de por qué no se contempla también la tipifica- 
ción de las mismas conductas de este delito, las cometidas por un funcionario público nacional o por funcionario público extranjero, frente a las del particular. En coherencia con el análisis efectuado en torno a los clásicos delitos de cohecho, así como en relación a la ubicación del soborno transnacional junto con el delito de corrupción entre particulares en la misma sección, capítulo y título del CP, debería haberse regulado el soborno pasivo transnacional. La corrupción pasiva se castiga para los delitos de cohecho contra la Administración Pública y para los delitos de corrupción entre particulares, aunque en estos últimos ilícitos no intervenga un funcionario público. No se entiende cómo se ha incorporado en el art. 286 ter la figura del funcionario público español y del funcionario público de la UE como sujeto que interactúa en el pacto corrupto y no se castiga su actuación como sobornador o sobornado. El castigo en España a un funcionario público extranjero sería inviable ${ }^{143}$, pero no lo sería si el agente público fuese español o, según los casos, de la UE. El cohecho clásico, que constituye un precepto más amplio y genérico que los delitos de corrupción en las transacciones comerciales internacionales, sí contempla el castigo de los funcionarios anteriormente citados. El Convenio del Consejo estableció además la obligación de la incriminación de funcionarios públicos extranjeros por los Estados parte ${ }^{144}$.

El art. 286 ter únicamente contempla la corrupción en su modalidad activa, pero no tipifica ningún castigo para el funcionario público. El legislador volvió, una vez más y tras la última reforma, a dejar impune el comportamiento de soborno del funcionario público en los delitos de corrupción en las transacciones comerciales internacionales. Esta laguna no tiene justificación, pues si por motivos procesales era difícil incriminar al funcionario público extranjero como único posible sujeto sobornable antes de la reforma, no lo es ahora, cuando se ha introducido en el tipo la variante de que el funcionario público también pueda ser español o de la UE, no sólo de un país extranjero. El legislador ha optado por no castigar la consiguiente conducta de corrupción pasiva del funcionario extranjero corrupto que solicita o recibe el beneficio o ventaja indebidos por su adjudicación o concesión de un contrato o negocio en el tráfico económico internacional. Para sancionar la conducta del funcionario público habrá que acudir

143 El Estado español, en su vertiente del ius puniendi, no ostenta soberanía para enjuiciar a funcionarios públicos extranjeros al servicio de un Estado extranjero (arts. 117.1 y 1.2 de la CE), y, por tanto, tampoco los Juzgados y Tribunales poseen potestad jurisdiccional al respecto (art. 2.1 LOPJ).

144 Art. 17 del Convenio del Consejo. 
a los delitos de cohecho pasivo cuando se trate de un funcionario público de la UE al que no le sean aplicables las inmunidades o prerrogativas de otro Estado comunitario o de un funcionario español. Sería recomendable que, en lugar de aplicar esas remisiones tácitas para colmar esta laguna de punibilidad, se hubiera introducido el castigo del funcionario en el propio art. 286 ter.

Es cierto que castigar al funcionario público extranjero por ofrecer o exigir un soborno tampoco hubiera supuesto la solución más realista, teniendo en cuenta que hasta ahora el CP sigue las pautas marcadas por el Convenio de la OCDE y de la legislación anticorrupción norteamericana que le sirve de modelo, la FCP ${ }^{145}$. La solución más acertada, en todo caso, consiste en reforzar y profundizar en la cooperación internacional, y que se establezca un principio de reciprocidad y de doble incriminación para el castigo de funcionarios públicos extranjeros que cometan cohecho transnacional. Sin embargo, cabe señalar que aunque ésa fuera la solución más acertada, no sería tampoco fácil, debido a que las carencias procesales podrían obstaculizar a menudo la investigación de los casos de corrupción en determinados Estados.

La nueva ubicación de estos delitos aquí examinados debe valorarse en relación con el análisis del antiguo precepto del art. 445, porque a pesar de que la sección $4 .^{a}$ de los delitos de la corrupción en los negocios comprenda también el delito de corrupción entre particulares, predomina la figura del funcionario público y la incidencia en el sector público que pueden tener los delitos del art. 286 ter. También hay que poner de relieve que los delitos de corrupción entre particulares constituyen un cohecho privado cuyo análisis, de igual modo, ha de remontarse mayormente a los delitos de cohecho, por lo que la comparación entre ambos injustos en este trabajo no hubiese arrojado luz más allá de lo que pudiera desprenderse del bien jurídico protegido, común a ambas conductas.

La protección del correcto funcionamiento del tráfico económico y comercial internacional ha de interpretarse como la protección a una competencia justa y honesta, pero en la vertiente de la función político-social que debe cumplir. Proteger la competencia ${ }^{146}$ debe entenderse como la protección de su función económica (calidad-precio) y de su función polí-

145 E. Fabián CAPARRós, La corrupción de agente público..., op. cit., p. 52.

${ }^{146} \mathrm{La}$ OCDE define al Derecho de la competencia como el cuerpo de leyes y reglamentos encargados de regular las prácticas empresariales. Vid. G. Mina y P. GibBons, Trade and Competition, International Trade Research Paper Series, Australia, Australian Government Publishing Service, 1995, p. 11 
tico-social (posibilidad de acceso a otros competidores y posibilidad de elección del consumidor) ${ }^{147}$. La imposibilidad de que otros competidores accedan a los negocios o contratos adjudicados al particular que ha sobornado al funcionario puede afectar a la capacidad de elección del ciudadano o consumidor y a la variedad de productos que se ofrecen en el mercado, pudiendo mermar la calidad por aumento y desequilibrio de los precios del competidor desleal. Asimismo se quebranta esta función político-social de la competencia leal del mercado, porque el funcionario debe velar no sólo por el cumplimiento reglado y honesto de sus funciones públicas, que deben contribuir al correcto funcionamiento de la Administración Pública, sino también por la salvaguarda del correcto funcionamiento del mercado a través de la justa y medida intervención del Estado en una economía de mercado ${ }^{148}$, e igualmente tendrá también la obligación de salvaguardar que desde ese Estado no se contribuya a irrumpir en la leal competencia del tráfico económico internacional ${ }^{149}$.

La libre competencia del mercado español respecto a las inversiones, transacciones comerciales, contractuales y la consecución de los negocios en el extranjero se verán quebrantados tanto si la autoridad o funcionario público sirve al Estado español como si sirve a otro Estado extranjero. Podrá afirmarse que se ha lesionado o que sólo se ha puesto en peligro el bien jurídico protegido en función de que se haya consumado la conducta y se haya obtenido el resultado o ventaja mediante el acuerdo corrupto. No obstante, tal diferenciación resulta en ocasiones imposible, porque la corrupción en sí comporta un riesgo de lesión a bienes jurídicos colectivos. En algunas circunstancias se materializan los efectos del delito en una lesión, en otras sólo comportan un peligro, a pesar de haberse consumado una conducta típica, antijurídica y culpable. La alteración del libre y regular funcionamiento del mercado no siempre trasciende a un perjuicio directo y concreto a los ciudadanos, de ahí que la mayoría de los delitos de corrupción se consideren delitos de peligro y de víctima difusa. Los delitos de corrupción en las transacciones comerciales internacionales son, por lo general, delitos de peligro concreto, pluriofensivos y de carácter semipúblico.

147 M. Bajo Fernández y S. Bacigalupo Sasse, Derecho penal económico, 2. ${ }^{a}$ ed, Madrid, Ceura, 2010, p. 476.

${ }^{148}$ Según el art. 38 CE, el concepto de economía de mercado reposa esencialmente en la libre competencia. Vid. H. DemseTz, La competencia..., op. cit., p. 25.

149 Entiéndase que el concepto de libre competencia tiene en cuenta tanto los bienes nacionales como los extranjeros. Ésa es una de las razones que justifican la profunda interrelación entre las políticas de libre competencia y el libre comercio. 
El bien jurídico protegido para todas las modalidades de los delitos de corrupción del art. 286 ter es el correcto funcionamiento del tráfico comercial y económico internacional, dentro del orden socioeconómico y en su vertiente de las condiciones de la libre competencia ${ }^{150}$. De forma colateral se tutela el interés público en el plano internacional y, dependiendo de si el funcionario público sirve al Estado español o a otro extranjero, se vulnerará también el correcto funcionamiento de la Administración Pública española o el prestigio e imagen del Estado español en las relaciones comerciales internacionales frente a la Administración Pública extranjera.

\section{CONCLUSIONES}

La corrupción y su crecimiento conforman el vasto ámbito donde se concretan los delitos de corrupción en las transacciones comerciales internacionales. El análisis del aspecto penal y económico de la corrupción explica la necesidad político-criminal de castigar las conductas corruptas en aquellas operaciones de comercio internacional en las que interviene un agente público. La corrupción se caracteriza y se comprende mejor al contextualizarla dentro de la cultura social, económica y política en la que se desarrolla. Hay que recordar que la corrupción acompaña los cambios de etapas históricas o ciclos económicos siempre que existen choques entre sentidos culturales más débiles, o que pertenecen a los periodos de decadencia del sistema democrático, el cual propugna los valores supremos de la justicia, la igualdad y la libertad. Los desajustes culturales que condu-

${ }^{150}$ I. VALEIJE ÁlvareZ «Breve reflexión sobre la modalidad de cohecho activo en las actividades económicos internacionales (art. 286 ter)», en J. L. GonZÁlez Cussac (dir.), A. Matallín Evangelio y E. GórRiz Royo (coords.), Comentarios a la Reforma del Código Penal de 2015, Valencia, Tirant lo Blanch, 2015, pp. 1170-1171. También en relación con el antiguo art. 445 estimó D. BENITO SÁNCHEZ, El delito de corrupción en las transacciones comerciales internacionales, Madrid, Iustel, 2012, que el bien jurídico afectado por la comisión de este delito se encontraba en estrecha relación con el funcionamiento de la Administración Pública del país del funcionario extranjero y además estaba vinculado a la competencia leal en el mercado internacional, que se vería vulnerada por la aparición en escena de elementos ajenos al libre juego de la oferta y la demanda como son los sobornos (p. 169). Por otro lado, también en relación con el antiguo art. 445, consideró M. Cugat MAURI, «La corrupción en las transacciones comerciales...», op. cit., que el Convenio de la OCDE pretendía que se protegiera penalmente el mercado, siendo el objeto de tutela de estos delitos la definición de lo que es objeto de interés público en el plano internacional y las competencias de los Estados en orden a su protección, el reconocimiento del especial poder que los funcionarios pueden tener en el mercado y la consiguiente necesidad de reprimir los abusos en su ejercicio (p. 332). 
cen a la corrupción presentan múltiples oportunidades para que ésta prolifere. Hoy día, la esfera pública y la privada se encuentran íntimamente mezcladas, con límites desdibujados, de forma tal que la confusión existente al tratar el tráfico económico y comercial transnacional desemboca en que determinadas conductas corruptas se amparen en la opacidad para obtener ventajas y ganancias indebidas. Se hacen necesarios, pues, nuevos mecanismos multidisciplinares a fin de combatir la corrupción transnacional. El Derecho penal debe ser la pieza de cierre de un sistema de armonización para hacer frente a la lucha contra la corrupción transnacional. Los nuevos retos se presentan a través de un amplio espectro de artimañas comisivas y de una nueva criminalidad empresarial que arraiga en las multinacionales. Las conductas delictivas son cada vez más sofisticadas y se aprovechan de las lagunas en la cooperación internacional político-criminal, así como en el derecho sustantivo y adjetivo; de esta forma se perpetran los delitos en la clandestinidad y logran la impunidad.

El soborno transnacional es el claro exponente que refleja la degeneración de nuestro sistema democrático globalizado y asentado en el capitalismo económico. La gravedad de los intereses jurídicos que se lesionan con este delito y la coherencia con la asunción de los compromisos internacionales, suscritos por España a través de las ratificaciones de Convenios internacionales, constituyen la razón por la cual este injusto merece haberse introducido en el CP.

Los delitos de corrupción en las transacciones comerciales internacionales son un tipo de soborno cuyas mutaciones han quedado probadas durante su evolución histórica, desde sus inicios hasta la actual regulación penal sustantiva. El cohecho transnacional sobrepasa realmente el contenido del delito analizado, a pesar de que el tipo del art. 286 ter acota al menos una modalidad específica del cohecho internacional: la que ataca el correcto funcionamiento del tráfico comercial internacional en la frontera donde confluyen los sectores público y privado.

La corrupción y la globalización han propiciado que el delito común de cohecho se transforme en una nueva infracción penal especial: el cohecho transnacional con funcionarios públicos extranjeros, aquellos que persiguen obtener un contrato o negocio en el marco económico internacional.

La tipificación de los delitos de corrupción en las transacciones comerciales internacionales adolece de ciertas deficiencias, si bien la incorporación y la última reforma legislativa en el CP que afecta al injusto denota un cierto grado de madurez por parte de España en la lucha contra este tipo de corrupción semipública internacional. 
La última reforma y ubicación sistemática de estos delitos, que ha tenido lugar mediante la creación de un nuevo precepto sin precedentes, responde a la correcta delimitación de un bien jurídico protegido pluriofensivo. Ello no llegó a formalizarse hasta la última y reciente reforma del CP, pues debido al desconocimiento de este tipo de corrupción en el momento de su introducción en el CP, junto a la confusión en torno a que interviniese un funcionario público, el paralelismo estructural que mostraba el ilícito con la figura clásica del cohecho y la falta de regulación de la corrupción privada en el CP por aquel momento, fueron las causas de que el pasado de estos delitos difiera de la actual regulación y ubicación sistemática.

$\mathrm{El}$ art. 286 ter transmite en general una sensación de angustia y falta de claridad; refleja un intento por abarcar en un único precepto nuevas formas de criminalidad de corrupción en los negocios, adaptando el CP a la realidad social, a las pautas marcadas por las revisiones de implementación de los documentos internacionales suscritos por España y queriendo respetar a la vez, pero en parte, la tradición histórica de la forma típica que posee el delito de cohecho en el CP. Se castiga sólo el soborno activo, lo que sería comprensible si el delito únicamente se cometiera con funcionarios públicos extranjeros, pues el Estado español no tendría jurisdicción para enjuiciar a dichos sujetos. La última reforma, sin embargo, introduce la posibilidad de que el soborno sea con un funcionario de la UE o con un funcionario español. En el caso de que sea un funcionario de la UE deberá acudirse al art. $427 \mathrm{CP}$, que contemplaba el soborno en general con este tipo de autoridades públicas. Tiene sentido, pues, que se unifique el soborno de funcionarios públicos extranjeros y el soborno de funcionarios de la UE en un mismo precepto, pero lo que no cuadra es que el tipo del art. 286 ter sea un delito más específico que el delito de cohecho clásico. El soborno contemplado en el art. 286 ter tiene lugar con objeto de obtener cualquier ventaja, negocio o contrato en el tráfico económico internacional, mientras que el art. 427 remite a cualquier clase de cohecho. Tales supuestos de cohecho contra la Administración Pública o contra el tráfico económico internacional no están unificados y dan lugar a provocar un concurso de leyes innecesario. Hubiera sido más recomendable introducir la definición de autoridad o funcionario público de la UE y extranjero en el art. 24 CP. De esta manera no tendría que recurrirse desde el art. 286 ter, ubicado dentro del título de los delitos contra el orden socioeconómico, al art. 427 CP, situado dentro del título de los delitos contra la Administración Pública. 
La ubicación actual de los delitos de corrupción en las transacciones comerciales internacionales es apropiada; no obstante, en el futuro podrá volver a quedar obsoleta esta reforma penal. El soborno transnacional reúne algunas de las características que podrían poseer otros delitos relacionados con la corrupción, dado que: su bien jurídico protegido es pluriofensivo, su estructura parte del clásico delito de cohecho y sus elementos típicos se han ido transformando y adaptando en función de la casuística de la criminalidad de la empresa y de la complejidad de los entramados para su ocultación. Como ya se mencionó, la corrupción descompone y desvía distintos valores e intereses jurídicos, y se desarrolla en función de cómo evoluciona culturalmente la sociedad en un marco sociopolítico y económico. Sin embargo, el concepto de corrupción es siempre el mismo con independencia de la época y de los casos, aunque las formas de su aparición y las lesiones que provoca sean cambiantes. De ahí que cualquier delito de corrupción esté sujeto a las continuas volatilidades y los cambios legislativos que van sucediéndose con el fin de adaptar la norma penal a los nuevos o distintos ataques a los bienes jurídicos. Tal vez ofrecería mayor seguridad jurídica y supondría un símbolo de garantía y permanencia el hecho de que existiera un título en el CP dedicado a la corrupción, dentro del cual se englobarían los distintos tipos de corrupción pública y privada. La delimitación entre corrupción privada y pública no siempre resulta sencilla, ya que lo público y lo privado en materia de corrupción se superponen permanentemente. En el caso de los delitos analizados se comercia con un poder en el sector privado, si bien este poder procede del ejercicio de un determinado cargo público dentro del sector público. Por ello no sería descabellado que todas las conductas corruptas se regulasen de forma correlativa en el CP, pues, a la vista de que la lucha contra la corrupción no ha llegado a su fin y los medios para combatirla surgen según las transformaciones de la misma, seguirán existiendo continuas modificaciones legislativas cada vez más sustanciales, siempre que se continúe anclando la ubicación de nuevas conductas a parámetros del pasado, que a veces ya están superados. La solución antes expuesta, aunque resulte la más práctica y simplista de cara a los delitos analizados, no casa bien con la tradición histórica del CP y precisaría de una profunda y compleja reforma penal, ya que supondría el cambio de criterio de la ordenación sistemática del $\mathrm{CP}$, a la vez que podría provocar una desestructuración de otros muchos delitos que están ligados a la corrupción, pero ubicados en los títulos correspondientes según el bien jurídico que protegen. 
Los delitos de corrupción del art. 286 ter atacan el correcto funcionamiento del tráfico comercial internacional dentro del orden socioeconómico establecido. La protección del correcto funcionamiento del tráfico económico y comercial internacional ha de interpretarse como la protección a una competencia justa y honesta, pero en la vertiente de la función político-social que debe cumplir. De forma colateral, y a tenor de si el funcionario público sirve al Estado español o a otro extranjero, se vulnerará también el correcto funcionamiento de la Administración Pública española o el prestigio e imagen del Estado español en las relaciones comerciales internacionales frente a la Administración Pública extranjera.

Por consiguiente, y en relación al bien jurídico protegido en estos delitos, la nueva ubicación en el CP mediante la reforma de la LO 1/2015 resulta la adecuada, encontrándose el art. 286 ter dentro de la sección $4 .{ }^{a}$, «De los delitos de la corrupción en los negocios», del capítulo XI, «Sobre los delitos contra el mercado y los consumidores», y del título XIII, «Sobre los delitos contra el orden socioeconómico». Todas las rúbricas del título, capítulo y sección citados se corresponden con los intereses jurídicos que vulnera el precepto analizado. El antiguo delito del art. 445 dentro del título XIX, «De los delitos contra la Administración Pública», fue catalogado por la doctrina como crónica de una muerte anunciada, pues cuando se introdujo por primera vez el art. 445 bis en el CP en el año 2000, el Convenio de la OCDE, el Convenio de la UE de 1997 y el Convenio penal del Consejo de Europa de 1999 dejaron entrever que ese tipo de corrupción se encaminaba al correcto funcionamiento del tráfico económico internacional.

\section{BIBLIOGRAFÍA}

Ades, A., y Di Tella, R., «Rents, Competition and Corruption», American Economic Review, vol. 89, núm. 4 (1999), pp. 982-993.

Aguado Correa, T., El principio de proporcionalidad en Derecho penal, Madrid, Edersa, 1999.

ArgandoñA, A., «Las empresas ante la corrupción», Papeles de Ética, Economía y Dirección, núm. 4 (1999), pp. 1-12, haciendo referencia a su vez a LYMANN, D., «Corruption faced by the business world. A primer», presentado al World Economic Forum 1996 Annual Meeting, Davos, 1996.

Arroyo Zapatero, L., y Nieto Martín, A., El Derecho penal económico en la era compliance, Valencia, Tirant lo Blanch, 2013.

Bacigalupo Zapater, E., Curso de Derecho penal económico, 2. ${ }^{\text {a }}$ ed., Madrid, Ediciones Jurídicas y Sociales, 2005. 
- «Sobre la reforma de los delitos de funcionarios», Documentación Jurídica, vol. II, núm. 37/40 (1983), pp. 1093-1105.

Barbero Santos, M., Estudios penales. Libro homenaje al profesor D. José Antón Oneca, Salamanca, Universidad de Salamanca, 1982.

Benito SÁnchez, D., El delito de corrupción en las transacciones comerciales internacionales, Madrid, Iustel, 2012.

Blanco Lozano, C., Tratado de Derecho penal español, t. II, El sistema de la Parte Especial, vol. 2, Delitos contra bienes jurídicos colectivos, Barcelona, Bosch, 2005.

Casas Barquero, E., «Algunos aspectos de los delitos del funcionario público y del particular relativos a dádivas, presentes, ofrecimientos o promesas», en Estudios penales. Libro homenaje al profesor D. Antón Oneca, Salamanca, Universidad de Salamanca, 1982, pp. 655-671.

Catalán Sender, J., Delitos cometidos por autoridades y funcionarios públicos en el nuevo Código Penal (doctrina y jurisprudencia), Barcelona, Bayer Hnos., 1999.

Ciuro Caldani, M. A., «Análisis cultural de la internacionalidad, la globalización y la integración», Revista del Centro de Investigaciones de Filosofía Jurídica y Filosofía Social, núm. 24 (2000), pp. 41-56.

Cobo del Rosal, M. (coord.), Derecho penal español. Parte especial, 2. ${ }^{a}$ ed., Madrid, Dykinson, 2005.

Córdoba Roda, J., y García ArÁn, M., Comentarios al Código Penal. Parte especial, t. II, Madrid-Barcelona, Marcial Pons, 2004.

Corominas, J., Diccionario crítico etimológico castellano e hispánico, vol. I, $A-C$, Madrid, Gredos, 1954-1957.

D’Ors y Pérez Peix, A., Elementos de Derecho privado romano, 4. ${ }^{\text {a }}$ ed., Pamplona, Eunsa, 2010.

De la Cuesta Arzamendi, J. L., «La criminalización de la corrupción en el sector privado: ¿asignatura pendiente del Derecho penal español?», en J. L. DíEz RIPOLlés (coord.), La ciencia del Derecho penal ante el nuevo siglo. Libro homenaje al profesor D. José Cerezo Mir, Madrid, Tecnos, 2002, pp. 257-290.

— «Iniciativas internacionales contra la corrupción», Eguzkilore, núm. 17 (2003), pp. 5-26.

De la Mata Barranco, N. J., «El bien jurídico protegido en el delito de cohecho», Revista de Derecho Penal y Criminología (RDPC), 2. época, núm. 17 (2006), pp. 81-152.

- Derecho penal europeo y legislación española: las reformas del Código Penal, actualizado a la reforma penal 2015, Valencia, Tirant lo Blanch, 2015.

Demsetz, H., La competencia: aspectos económicos, jurídicos y políticos, Madrid, Alianza Editorial, 1986.

Díaz Maroto y Villarejo, J., «El delito de corrupción en las transacciones económicas internacionales (art. 445 del Código Penal) (1)», La Ley, año XXVIII, núm. 6.740 (2007), pp. 1904-1914.

Díez Ripollés, J. L. (coord.), La ciencia del Derecho penal ante el nuevo siglo. Libro bomenaje al profesor D. José Cerezo Mir, Madrid, Tecnos, 2002. 
Durant, W., Our Oriental Heritage, The Story of Civilization, vol. I, New York, Simon \& Schuster, 2011.

FABIÁn CAPARRÓs, E., La corrupción de agente público extranjero e internacional, Valencia, Tirant lo Blanch, 2003.

Feijoo Sánchez, B., «El delito de corrupción de agentes públicos en actividades económicas internacionales del art. 286 ter CP como delito contra la competencia a través de la corrupción», Diario La Ley, núm. 8.987 (2017).

GaRCía ArÁn, M., El fenómeno de la internacionalización de la delincuencia económica, en Estudios de Derecho Judicial, núm. 61 (2004).

Gili Pascual, A., «Bases para la delimitación del ámbito típico en el delito de corrupción privada (contribución al análisis del art. 286 bis del Código Penal según el Proyecto de reforma de 2007)», Revista de Derecho Penal y Criminología, núm. 19 (2007), pp. 245-288.

GonzÁlez Cussac, J. L., El delito de prevaricación de funcionario público, Valencia, Tirant lo Blanch, 1994.

González Cussac, J. L. (dir.); Matallín Evangelio, A., y Górriz Royo, E. (coords.), Comentarios a la Reforma del Código Penal de 2015, Valencia, Tirant lo Blanch, 2015.

Granados Pérez, C., «El instrumento en el delito de cohecho», Cuadernos de Derecho Judicial, núm. 4 (1994), pp. 129-152.

HEFENDEHL, R., «¿Debe ocuparse el Derecho penal de riesgos futuros? Bienes jurídicos colectivos y bienes de peligro abstracto», Revista Electrónica de Ciencia Penal y Criminología, núm. 4 (2002).

Heine, G., y Rose, T., Private Commercial Bribery (A Comparision of National and Supranational Legal Structures), Freiburg, Max Planck-Institut, 2003.

Iglesias Río, M. A., y Medina Arnáiz, T., «Herramientas preventivas en la lucha contra la corrupción en el ámbito de Unión Europea», en AAVV, Anuario de Derecho Constitucional Latinoamericano, t. II, Montevideo, Konrad Adenauer Stiftung, 2004.

Johnston, M., «Party System, Competition and Political Checks against Corruption», en A. J. Heidenheimer y M. Johnston (eds.), Political Corruption. Con-

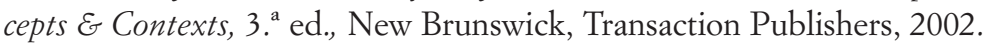

KINDHÄUSER, U., «Presupuestos de la corrupción punible en el Estado, la economía y la sociedad. Los delitos de corrupción en el Código Penal alemán», Politica Criminal. Revista electrónica semestral de políticas públicas en materias penales, núm. 3 (2007).

López Barja de Quiroga, P., Historia de Roma, Madrid, Akal, 2004.

López Barja de Quiroga, J.; Rodríguez Ramos, L., y Ruiz de Gordejuela López, L., Códigos Penales españoles. Recopilación y concordancias, Madrid, Akal, 1988.

Luzón Cuesta, J. M., Compendio de Derecho penal. Parte especial, 12. ${ }^{a}$ ed., Madrid, Dykinson, 2004. 
Manfroni, C., Soborno transnacional, Buenos Aires, Abeledo-Perrot, 1998.

Maquiavelo, N., y Aracón Martínez, A., Discursos sobre la primera década de Tito Livio, Madrid, Alianza Editorial, 1987.

Memento Práctico, Penal Económico y de la Empresa, Madrid, Francis Lefebvre, 2016-2017.

Mir Puig, S., Derecho penal. Parte general, 9. a ed., Barcelona, Reppertor, 2011.

Mir Puig, C., Los delitos contra la Administración Pública en el nuevo Código Penal, Barcelona, Bosch, 2000.

Morales Prats, F., y Rodríguez Puerta,M. ${ }^{a}$ J., «Título XIX. Delitos contra la Administración Pública», en Quintero Olivares (dir.), Comentarios a la parte especial del Código Penal, 5. ${ }^{a}$ ed., Elcano, Aranzadi, 2005.

Müller, C., Die Bestechung gemäss $\$ 4$ lit.b UWG, Bamberg, Difo Druck GmbH, 1997.

Muñoz Conde, F., Derecho penal. Parte especial, 13. ${ }^{a}$ ed., Valencia, Tirant lo Blanch, 2001.

Muñoz de Morales Romero, M., El legislador penal europeo: legitimidad y racionalidad, Madrid, Civitas, 2011.

Navarro Massip, J., «El delito de corrupción entre particulares», Revista Aranzadi Doctrinal, núm. 8 (2011), pp. 41-54.

Nieto García, A., Corrupción en la España democrática, Barcelona, Ariel, 1997.

Nieto Martín, A., «La corrupción en el comercio internacional (o de cómo la americanización del Derecho penal puede tener de vez en cuando algún efecto positivo)», Revista Penal, núm. 12 (2003), pp. 3-26.

Nino, C., Un país al margen de la ley, 1. ${ }^{a}$ ed., Buenos Aires, Ariel, 2005.

Octavio de Toledo, E., «Derecho penal, poderes públicos y negocios (con especial referencia al cohecho)», en AAVV, El nuevo Código Penal: presupuestos y fundamentos. Libro bomenaje al profesor Torio López, Granada, Comares, 1999, pp. 861-878.

- La prevaricación del funcionario público, Madrid, Civitas-Instituto de Criminología de la Universidad Complutense de Madrid, 1980.

Olaizola Nogales, I., El delito de cohecho, Valencia, Tirant lo Blanch, 1999.

Orts Berenguer, E., et al., Derecho penal. Parte especial, 3.a ed., Valencia, Tirant lo Blanch, 2004.

Otero GonzÁlez, P., «Corrupción entre particulares (delito de)», Eunomía. Revista en Cultura de la Legalidad, núm. 3 (2012), pp. 174-183.

- «Los nuevos delitos de corrupción en los negocios tras la reforma penal por LO 1/2015 (análisis de cuestiones concretas de los arts. 286 bis y 286 ter CP)», en M. Villoria Mendieta, J. M. Gimeno Feliú y J. Tejedor Bielsa (dirs.), La corrupción en España. Ámbitos, causas y remedios jurídicos, Barcelona, Atelier, 2016, pp. 451-496.

PIREnNe, J., Historia Universal, vol. I, Barcelona, Éxito, 1959.

Quintero Olivares, G. (dir.), Comentarios a la parte especial del Código Penal,

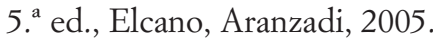


Rodríguez Almirón, F., «La responsabilidad penal de las personas jurídicas a raíz de la jurisprudencia reciente del Tribunal Supremo», Revista Aranzadi Doctrinal, num. 6 (2017), pp. 107-129.

Rodríguez Puerta, M. J., «La responsabilidad del particular en el delito de cohecho. Comentarios de la Sentencia del Tribunal Supremo de 29 abril 1998», Revista de Derecho y Proceso Penal, núm. 1 (1999), pp. 183-210.

Rose Ackermann, S., Corruption: A Study in Political Economy, New York, Academic Press University of Yale, 1978.

Roxin, C., Täterschaft und Tatherrschaft, 7. . ed., Berlin, De Gruyter, 2006.

Sainz Guerra, J., La evolución histórica del Derecho penal español, Jaén, Servicio de Publicaciones e Intercambio de la Universidad de Jaén, 2004.

Sánchez Albornoz, C., España: un enigma bistórico, vol. II, Argentina, Edhasa, 1991.

Serrano Gómez, A., Derecho penal. Parte especial, Madrid, Dykinson, 2001.

Tiedemann, K., Manual de Derecho penal económico. Parte general y especial, Valencia, Tirant lo Blanch, 2010.

VAleije Álvarez, I., El tratamiento penal de la corrupción del funcionario: el delito de cohecho, Madrid, Edersa, 1996.

- «Consideraciones sobre el bien jurídico protegido en el delito de cohecho», Estudios Penales y Criminológicos, núm. 18 (1994-1995), pp. 295-369.

Ventura PÜschel, A., «Corrupción entre particulares», en F. J. Álvarez García y J. L. GonzÁlez Cussac (dirs.), Comentarios a la reforma penal de 2010, Valencia, Tirant lo Blanch, 2010.

Villoria Mendieta, M.; Gimeno Feliú, J. M., y Tejedor Bielsa, J. (dirs.), La corrupción en España. Ámbitos, causas y remedios jurídicos, Barcelona, Atelier, 2016.

Vives Antón, T., «La responsabilidad de los jueces en el Proyecto de la Ley Orgánica del Poder Judicial», Estudios Penales y Criminológicos, núm. 9 (1984-1985), pp. 257-280.

VolK, K., Empfeblen sich Änderungen des Straf-und Strafprozessrechts, um der Gefahr von Korruption im Staat, Wirtschaft und Gesellschaft wirksam zu begegnen? Verbandlungen des einundsechzigsten deutschen Juristentages, vol. II/1, Sitzungsberichte-Referate und Beschlüsse, München, Bek'sche Verlagsbuchhandlung, 1996.

Wagner, H., Amtsverbrechen, Berlin, Dunker \& Humblot, 1975.

ZAFFARONI, E. R., «La globalización y las actuales orientaciones de la política criminal», Direito e Ciudadania, año III, núm. 8 (1999-2000), pp. 71-96.

Zugaldía Espinar, J. M. (dir.), y Moreno Torres Herrera, M. J. (coord.), Lecciones de Derecho penal (parte general), 2. ${ }^{\text {a }}$ ed. adaptada a la reforma del Código Penal aprobada por las Leyes Orgánicas 1 y 2/2015, de 30 de marzo, Valencia, Tirant lo Blanch, 2015. 